\title{
Before, Now, and After the Event of Terror: Situational Terror Awareness for Civilians in US Homeland Security
}

\author{
Kerrin-Sina Arfsten ${ }^{1}$ (iD
}

Received: 4 February 2019 / Accepted: 18 October 2019 / Published online: 6 November 2019 (c) The Author(s) 2019

\begin{abstract}
This article examines terror awareness as an individualized security practice that allows civilians to respond to situations of emergent terror as they occur, that is, in real time. It is a practice that targets the "time-space" (Walters in Comp Eur Polit 15(5):794-817, 2016) just before, during, and immediately after an event of terror. In recent years, the notion of "terror awareness" has gained salience in official US homeland security discourses. To protect themselves and their communities from harm and ensure an uninterrupted "way of life," citizens are routinely encouraged to be vigilant and aware to signs of potential terror as they attend to their daily affairs. They are asked to stay informed, remain alert, and be ready to respond to the incipiency of terror so that they may avert—or, at least mitigate—its potentially catastrophic and disruptive consequences. According to the authorities, this kind of habitualized threat awareness can help prevent acts of terror and strengthen community resilience. But what exactly do government and security officials mean when they speak of "terror awareness"? What does this practice of being "terror aware" entail? And how is it supposed to function as a protective mechanism against potential terror? What is its relationship to such abstract concepts as "security," "preparedness," and "resilience"? This article seeks to answer these questions. It is based on a careful reading of official and publicly available texts (press statements, policy documents, reports, training brochures, websites, etc.) about homeland security and anti-terrorism, where the notion of "awareness" finds mention and a specific understanding of it—namely as an individualized security technology—is being communicated to the wider public.
\end{abstract}

Keywords Homeland security · Situational awareness $\cdot$ Preparedness $\cdot$ Resilience Anti-terrorism

Kerrin-Sina Arfsten

kerrin.s.arfsten@gmail.com

1 Max-Planck-Institute for Foreign and International Criminal Law, Günterstalstr. 73,

79100 Freiburg im Breisgau, Germany 


\section{Introduction}

In October 2017, Sayfullo Saipov drove a rented Home Depot pickup truck down a busy bicycle path near the World Trade Center in New York City, killing eight and injuring almost a dozen (Prokupecz et al. 2017). In October 2018, Robert D. Bowers, armed with an AR-15-style assault rifle and at least three handguns, opened fire inside the Tree of Life Synagogue in Pittsburgh, Pennsylvania, killing 11 congregants (DOJ 2018a). The attack constituted the worst anti-Semitic attack in the nation's history (Robertson et al. 2018). At the same time, another violent extremist mailed pipe bombs to thirteen former high-ranking government officials in one of the nation's largest assassination attempts (DOJ 2018b). In April 2019, Rondell Henry was arrested for allegedly planning to use a stolen rental truck to mow down pedestrians at a popular Washington-area dining and shopping destination (Tau 2019). In August 2019, Patrick Crusius, armed with a rifle, entered a crowded Walmart store in El Paso, Texas, shooting and killing twenty unsuspecting shoppers (Romero et al. 2019). Cases such as these demonstrate that domestic terrorism is a significant threat currently facing the American homeland. The threat from violent extremism-especially right-wing extremism-is growing; the frequency and lethality of attacks appears to be on the rise (Jenkins 2017). ${ }^{1}$ Yet, the threat of violent extremism presents law enforcement and security officials with a challenge: it is diverse, fluid, volatile, and unpredictable (Jenkins 2017). As the National Strategy for Counterterrorism (WH 2018) notes, the country is facing a range of homegrown terrorist threats, motivated by a mix of ideologies. There is no typical demographic profile of who the perpetrators are (Horgan 2008). "[T]he terrorists who threaten America's safety" (WH 2018: preface) hail from various backgrounds. What is more, they are radicalizing quickly through social media and the Internet; are increasingly acting without a clear group affiliation or guidance; and are using "simple tactics against predominantly soft targets" (WH 2018: 8; see also FBI 2019). On top of that, the threat seems pervasive. FBI Director Christopher Wray recently remarked: "Today's terrorism threat is everywhere, coast to coast, north, south, east, west" (cited in Moore 2018). And in the Preface to the National Strategy (WH 2018), US President Donald Trump surmises: "the terrorist threat ha[s] become more complex and widespread than ever before."

To govern this complex and pervasive threat posed by domestic terrorism, the US government and its security authorities have decided to pursue what they call an

\footnotetext{
1 Terrorism worldwide has dropped dramatically between 2014 and 2017, but the frequency of extremist incidents in the USA has more than doubled in the same period (29 cases in 2014 to 65 in 2017) (Becker 2019: 1). What is more, for the first time in US history, the number of FBI investigations into domestic terrorism cases now equals the number of foreign terrorist cases (Hosenball 2018). Among those cases, a majority are related to right-wing extremism. "Although many Americans view Islamic terrorists as the greatest threat to the country, US-born far-right extremists have been responsible for three times more attacks," Cronin (2019), a researcher at the American Security Project, a non-partisan public policy and research organization dedicated to national security issues, explains. According to the Anti-Defamation League (ADL), a leading anti-hate organization in the USA, from 2009 through 2018, right-wing extremists accounted for $73 \%$ of extremism-related killings in the USA, compared with $23 \%$ for Islamists and $3 \%$ for left-wing extremists (see https://www.adl.org/media/12480/download).
} 
"all-of-nation" approach: they are rallying the entire society in their efforts aimed at providing homeland security. "Homeland security is a shared responsibility," they never tire to repeat. For the authorities, it is crucially important that all levels of government-federal, state, and local-as well as the private sector and private citizens are engaged in the fight against homegrown terrorism. On its website, the US Department of Homeland Security (DHS) (n.d.) notes, "Americans all share responsibility for the nation's security and should always be aware of the heightened risk of terrorist attack in the USA and what they should do" (emphasis added). But what exactly should private citizens do? How can they help prevent future acts of terror? Here, the official message is clear: American citizens should be "aware, alert, and ready to respond to keep our country safe" (DHS 2017). They should "be aware of their surroundings and report suspicious or unusual behavior to the authorities" (DHS 2018a: 2). They should "pay attention," because their awareness "may help prevent or deter an attack in places frequented by all of us" (TSA 2014). The creation of an aware and resilient public is one element that, according to the authorities, provides a "foundation for future success in homeland security" (DHS 2018b). For them, terror awareness practiced by an "informed and alert" citizenry is "a critical component of [the nation's prevention] architecture" (WH 2018: 21). After all, by lending the authorities their "eyes and ears," these alert citizens can serve as human sensors and "early warning systems" for the detection of imminent attacks (WH 2018: 21).

The governmental interpellation of citizens as private terror detectors is supported by various (state and non-state) institutions and organizations who are offering guidance and training for anyone interested in becoming more terrorism aware. Many of these training opportunities are directed at public sector entities who work in security-critical fields, such as law enforcement, emergency response, crisis management, or transportation (Shapiro et al. 2019). But an increasing number also address private sector entities and civilians. The Counterterrorism Education Learning Lab's Community Awareness Program (CAP), the Community Anti-Terrorism Training Institute's Anti-Terrorism Awareness Training for Citizens, or the North Carolina Justice Academy's Basic Anti-Terrorism Awareness course are examples. ${ }^{2}$ In addition, numerous manuals, guides, and self-help books have been published that provide advice on how to become more "terrorism aware." They include such titles as retired US army Lieutenant Colonel Joseph A. Ruffini's (2006) When Terror Comes to Main Street: A Citizen's Guide to Terror Awareness, Preparedness and Prevention or retired US Air Force Colonel Mike Licata's (2008) Citizens Terrorism Awareness and Survival Manual. What these initiatives share with the official narrative is that they all consider a well-trained and security conscious citizenry to be able to act as a powerful "force multiplier" (FEMA 2012) for the recognition and reporting of activities potentially indicative of terrorism (see also ODNI 2017). They also agree that being "informed and alert" will allow citizens to "take

\footnotetext{
${ }^{2}$ See, for example, https://www.thecell.org/; http://cateyes.us/; https://ncja.ncdoj.gov/getdoc/d2ab3 4c3-f897-408b-88ec-06f9ba6296ae/Basic-Anti-Terrorism-Awareness.aspx (last accessed: 11 August 2019).
} 
a stronger role in [their] own protection" (FEMA n.d.). Indeed, all these efforts are characterized by an underlying conviction that terror awareness is an effective security technique which enables citizens "to successfully recognize, report, and react to potential terrorist incidents" (FEMA n.d.). They argue that it not only allows civilians to see potential threats before-and as-they develop but also empowers them to become more resilient, that is, able to withstand the effects of attacks that could not be prevented. In this way, terror awareness is said to serve as "one of the key building blocks of effective personal security, and when practiced collectively, national security" (Stewart 2010).

In this article, I examine "civilian terror awareness" as precisely such a central, individual-level tactic for governing, and ideally preempting, acts of terror. I do not address terror awareness as it is practiced on the institutional level, for example, in the DHS's Fusion Centers, where it is much more concerned with building efficient networks of collecting, processing, and sharing time-sensitive and securitycritical information about emerging threats for incident management decisions (see, e.g., Regan et al. 2013). At the institutional level, terror awareness is very much a virtual(ized) process that reflects the necessities of contemporary network-centric, information-based warfare. It is a risk-assessment process where situational "threat pictures" are composed from heterogeneous data flows that are analyzed through automated suspicion algorithms (ASAs) and where decisions are made based on these actuarial calculations (Joh 2016; Knorr Cetina 2009; Rich 2016). In this article, by contrast, I am interested in the concretely situated practices of perception and attention-management that terror awareness entails when carried out by ordinary citizens. As such, my analysis furthers our understanding of how governmental authorities are mobilizing, shaping, and enlisting the affective and perceptual powers of everyday citizens in their efforts to counter perceived threats of terror. This, in turn, provides insights into the way security is governed in relation to the possibility of future terror, especially with regard to its normalization and integration into everyday life. Finally, this analysis also illustrates how abstract concepts such as "preparedness" and "resilience" are operationalized and translated into concrete practice.

The article proceeds as follows. First, I present some theoretical context. I discuss how the changed perception of the nature of the terror threat in recent years has increasingly turned governmental attention to situations of terror emergence(y), as a means for managing the threat as it occurs, that is, in real time. And I provide some reflections on what kind of "situation" terror-aware civilians are asked to pay attention to and why. Then, I review some of the existing literature on situational awareness and discuss its relevance for understanding how civilians are instructed to be terror aware in current discourses of homeland security. Having introduced the theoretical backdrop for my analysis, I subsequently focus my attention on the practice of terror awareness itself. I explore the specific attitude that is necessary for being "terror aware" and present four components of terror awareness that help us understand what this security practice entails and how it shapes the perceptions of civilians in anticipation of future threat. These components are a (1) a spatial component, (2) a cultural-normative component, (3) a temporal component, and (4) an affective component. I also explore how terror awareness as an individualized security practice 
introduces what O'Malley (2010) calls a "warrior" logic and, thereby, operationalizes such abstract ideas as preparedness/resilience. Finally, to conclude this article, I relate terror awareness to its historical antecedents, highlight how it differs, and why further research to understand this phenomenon is needed.

\section{The Government of Terror Through Situations}

Before I begin my analysis of terror awareness as an individualized security practice, let me briefly provide some theoretical context. In particular, I want to discuss a shift in security thinking that has occurred recently and turns attention to governing terror through the situations in which its potential exists and becomes recognizable. This perspective draws on insights from approaches to the situational prevention of crime (see Clarke and Newman 2006; Freilich and Newman 2009; Schmid 2012) in that it takes into account the immediate environment in which attacks occur and attempts to manipulate the situational conditions such that a motivated attacker is either deterred or detected in a timely enough matter to prevent or mitigate harmfor example, because of the increased visibility provided by the "eyes and ears" of watchful citizens. Because the concept of a "situation" is not easily interpreted, it is useful to delineate in what sense I am using it here. Also, an overview of the reasoning behind the shift in governmental focus to situations with the potential for terror helps to situate the practice of terror awareness in its appropriate socio-political context.

The Cambridge Dictionary defines "situation" as "the set of things that are happening and the conditions that exist at a particular time and place." Sociologists LaFree and Birkbeck (1991) offer a slightly different definition. According to them, a situation is "the perceptive field of the individual at a given point in time" (75). A review of the literature suggests that both definitions make "situations" sound simpler than they are (see, e.g., Friedrichs 1974). Conceptually speaking, "situations" are multiple in that they pre-exist participation in them and exceed their localized instances (Zigon 2015: 503). As Zigon (2015) describes it, situations are "constituted by diverse phenomena that become intertwined and emerge temporarily as localized manifestation" (503). At the same time, they are singular in that a particular constellation of people and things in a given time-space is always unique; the same constellation of interdependent elements will never spontaneously repeat itself (Stebbins 1967: 154). Thus, every situation has its distinct conditions of possibility (Walters 2016). Furthermore, every situation is open to different-sometimes conflicting-interpretations and definitions. On an institutional level, for example, the "situation" for terror awareness is "thick" and encompasses a large assemblage of heterogenous elements; its meaning is determined by an algorithmic, actuarial analysis of data flows (see Walters 2016: 806; Knorr Cetina 2009). Due to its largely virtual character, Knorr Cetina (2009) describes it as a "synthetic situation." As I will show, this is not the case with civilian terror awareness, which involves an immediate sensing and reading of the situation by individuals who are immersed in it. Here, the situation is defined by the perceived reality of the persons within it and how they make sense of it, for example, through experiential and mediated 
knowledge, associations, beliefs, or the affects they ascribe to it ("dangerous," "terrorizing," "harmless," "sketchy," "tense," etc.) (Thomas 2007; Goffman 1964, 1971, 1974). In practices of civilian terror awareness, people are an integral part of the situation. After all, it is impossible for them to perceive a situation of emergent terror without being physically present or enfolded in it. Hence, terror-aware individuals are always, at the same time, perceivers and participants-and therefore coproducers - of the situation (Goffman 1964, 1971). In the case of terror awareness, then, the definition of a situation is highly subjective. What is more, this subjective definition of the situation influences how citizens act in it and what role they decide to play (Blumer 1962: 145; see also Thomas 2007; Friedrichs 1974). The definition of a situation precedes and limits any possible action. To a great extent, it "provides the conditions for possible ways of being, doing, speaking, and thinking within that situation" (Zigon 2015: 503).

The shift to governing terror through situations in homeland security stems from the recognition that, in a threat environment where perpetrators radicalize quickly and are difficult to identify_ and thus act upon — before they begin to carry out their attacks, traditional preventative measures only go so far. As the DHS (2018b) notes, "highly lethal attacks ... can be executed with little planning or expertise and are often able to remain undetected until operational" (2). There are multiple pathways to radicalization (Horgan 2008; McCauley and Moskalenko 2008). And I mentioned above that there is no clear "terrorist profile." In addition, recent research suggests that perpetrators are increasingly trying to be even less visible and conspicuous (see Jones 2018). Ben Daley, a white supremacist of the Rise Above Movement (RAM), for example, has instructed his supporters to wear clothing like polo-style shirts and khakis and get clean-cut military-style haircuts to become less predictable (Jones 2018). According to Seth Jones (2018), researcher at the Center for Strategic \& International Studies (CSIS), Islamic extremists are similarly adopting tactics to remain "unseen," such as trimming their beards or wearing Western-style clothing. Finally, an increasing number of perpetrators are untethered to specific organizations. Among all threat actors these so-called "lone wolves" are especially difficult to detect. In fact, a study conducted by Smith et al. (2015) has shown that they not only carry out their preparatory activities further from their residences than perpetrators who are affiliated with a group/cell, but also travel further from their residences to strike a desired target. What is more, they also tend to be much more isolated. These factors, the authors conclude, conceivably reduce opportunities for preventative intervention (23).

The government of terror is thus characterized by a large degree of uncertainty. Under these conditions, the specific form of the threat and who poses it may be impossible to predict. It is more likely that the threat remains shrouded in secrecy until the moment it reveals itself and begins to materialize. Ultimately, the authorities therefore suggest, the only point of intervention may be the emergent event of terror itself. There may be, as the DHS (2011a) postulates, "nothing...to interrupt until something actually occurs." Consequently, law enforcement attention has shifted to the situation of terror's emergence-or, the emergence(y) situation. From this perspective, it becomes important to be able to recognize a situation with the potential for terror as soon as possible, that is, to become aware of it just in time 
before the threat fully materializes, and to be able to respond to it as quickly and efficiently as possible to eliminate or mitigate harm. The "situation" becomes, as Walters (2016) has noted, "a mode of grasping and acting on the event" of terror as it occurs (808, emphasis added). And, fortunately, this situation can be identified by sets of indicators-or, "warning signs"- that law enforcement agencies across the country have developed. These indicators can be located in situations that appear "out of the ordinary" or "unusual" in the here and now. They signal that the beginning of a situation which carries within itself the potential for disruption and violence is marked by a noticeable change in or deviation from the ordinary way of life. Delineated thusly, the "situation" "opens up a space of analysis around and in the interstices of the event" of terror (Walters 2016: 808).

To sum up, the focus on situations reflects an understanding of terror as imminent to everyday life and of the present as permanently on the verge of its emergence (Anderson 2010; Bratich 2002, 2006). It also goes hand-in-hand with the recognition that today's terror threats are so complex, variegated and fluid that any attempt to understand them can only take place after-the-fact, that is, with hindsight (Chandler 2014: 443). Where violence erupts unexpectedly, it may only be possible to be "wise after the event" (Prins 1991). It follows that all which can possibly be done beforehand is to anticipate the threat's emergence and to, ideally, intercept it-even if only at the very moment of its unfolding. After all, the only chance of stopping future acts of terror may be at their incipiency, moments before the dangerous future begins to unravel, shortly before the point of irreversibility. This time-space immediately preceding an attack, in-between radicalization and terror, is the object of terror awareness as a governmental technique. It is the "perceptive field" (LaFree and Birkbeck 1991) from and within which terror begins to materialize and become accessible to intervention. As a security technology, civilian terror awareness serves to discern the potential for danger within this perceptive field, to detect the event's "early warning signs" in an individual's immediate surroundings, so that appropriate and timely actions may be taken in response. In this way, while the boundaries of "situations" may be fluent and drawn only instantaneously, the governmental focus on them nevertheless constitutes an attempt at immobilizing, at least for an instance, the continuous flow of the future, of making it inhabitable long enough to make a decision and enable action that can avert disaster or mitigate harm.

\section{Terror Awareness as Situational Awareness}

Another body of literature is relevant for understanding contemporary terror awareness. As noted in the introduction, to practice terror awareness, the US authorities are routinely encouraging civilians to monitor their surroundings. The practice of monitoring one's surroundings for situations of emerging threat is also known as "situational awareness." And, indeed, in homeland security discourses the terms are often used interchangeably. Existing research on situational awareness reveals additional logics that are at work in terror awareness. It helps to grasp terror awareness as a distinct spatiotemporal practice and an amalgam of different governing rationalities. It also serves as a good starting point for our inquiry. At the very least, it 
provides us with some key components-or analytical dimensions-that we can later use to structure our investigation of terror awareness as an individualized security practice.

"Situational awareness" is a concept that has its roots in the fields of air traffic control, airplane cockpit control, manufacturing process control, military command and control, and information or network-centric warfare (O'Connor2019; see also Matheus et al. 2003). In fact, most of the existing literature on situational awareness is related to aviation or military matters (see, e.g., Finney 2008; Juarez-Espinosa and Gonzalez 2004; Nolan et al. 2014; NRC 1998). In the military context, for example, situational awareness is linked to effective combat decision-making in tactical environments and considered "critical to successful combat performance" (NRC 1998: 175). Based on this concept, advanced skills of surveillance, counter-surveillance, operational security and behavioral profiling have been developed (McGovern 2011: 56). Other fields in which the concept of situational awareness plays a role are emergency or incident management, law enforcement/criminology, psychology, business, medicine, and computer science (see, e.g., Matheus et al. 2003; Stewart 2010; Verma et al. 2011; Vieweg et al. 2010). Here, too, situational awareness is described as a crucial skill for the accomplishment of variety of operational tasks. It is presented as an important and effective technique for making decisions in complex, dynamic, fluid, and uncertain environments (Harrald and Jefferson 2007; Nolan et al. 2014). The concept pertains to situations where the variables factoring into decision-making are innumerable and constantly changing and the consequences of inaccurate assessments can be costly if not catastrophic (Endsley 1995; Metalis 1993; Vieweg 2012). However, situational awareness is not only practiced and used in extraordinary or high-risk contexts; it is also an important component of the skillful and safe performance of a range of ordinary activities, such as driving cars or playing (team) sports (Gugerty 2011; Jannat et al. 2018; Kass et al. 1990: 1352; Peck et al. 2016: 800). It is, thus, not per se an exceptional practice.

Although situational awareness seems to be accepted as an important concept across a variety of disciplinary fields, no common definition of it exists. Most definitions of situational awareness are rather technical. Among the more technical definitions of situational awareness, engineer and former Chief Scientist of the United States Air Force Mica Endsley's (1995) definition is perhaps the most prominent and widely used. Endsley defines situational awareness as "the perception of the elements in the environment within a volume of time and space, the comprehension of their meaning, and the projection of their status in the near future." (I will use these three components - perception, comprehension, and projection-to guide and structure my own analysis later on.) But there are also simpler, less technical definitions of situational awareness. Technology and media scholar Vieweg (2012), for example, describes situational awareness as "knowing what is happening in your immediate environment and understanding what that information means for a particular situation-including perception of the elements in the environment and how they relate to one another" (1). In the context of crime and terrorism, security consultant Stewart (2012) refers to situational awareness as: "being aware of one's surroundings and identifying potential threats and dangerous situations." McGovern (2011) adds an element of action to the definition when he argues that situational awareness 
means "recognizing a potential threat at an early enough state to allow counter measures to be taken to avoid it" (56). And, finally, in everyday parlance, the term situational awareness simply means "knowing what is going on around you" (see Jeannot et al. 2003; O’Connor 2019).

Despite their subtle differences, these definitions all describe a common goal for the practice of situational awareness: to gather all knowledge that is accessible in one's immediate environment through perception and that (a) can be integrated into a coherent picture of a complex and evolving but possibly critical situation and (b) can enable near real-time decision-making/action. Importantly, situational awareness denotes not a state of knowledge but the process whereby knowledge and understanding of a situation is achieved (see NRC 1998). Uncertainty is the norm in situations where situational awareness becomes relevant as a self-protective practice. The situation is indeterminate in nature; it is still evolving, and the outcome-what the situation will become-is contingent. But the purpose of situational awareness is not to come to a full understanding of a situation; it is to render the emerging situation knowable enough to enable decision-making and action. In the context of situational awareness, therefore, perception is purposeful; it serves the extraction of specific information, which is related to the task at hand (in this case, seeing and recognizing terrorism pre-incident indicators), from the environment. It is an active perceiving of the environment with the aim of understanding — or gaining knowledge about-a situation through a sensory sampling of it (see Vidulich et al. 1994). The information which a situationally aware individual seeks to extract is thus tactical, actionable information that can provide insights into time- and security-critical situations, such as a situation of possibly emergent terror (see Verma et al. 2011).

\section{Terror Awareness as a "State of Mind" and a "State of Attention"}

Against this theoretical backdrop, let us now take a closer look at discourses of civilian terror awareness in the USA and how the concept is used there. The definitions above are not specific enough to know exactly what the concept of "terror awareness" entails. For example, they tell us nothing about how it structures human attention and shapes perception in line with homeland security ideology-or how it translates into concrete, everyday practice. How, for example, are civilians supposed to come to an understanding of a situation as potentially related to terror? How do they come to define situations as potentially threatening, despite the given uncertainties? Furthermore, the definitions do not tell us how the practice of terror awareness gives material form to such abstract ideas as "security," "preparedness," or "resilience," that is, how these ideas are operationalized through practices of terror awareness. To gain a better understanding of these aspects of civilian terror awareness, we must dig deeper. At this point, I'd like to begin my analysis by exploring two essential requirements that official materials suggest must be met before an individual can successfully practice terror awareness: firstly, an individual must have the right "state of mind" and, secondly, also be in the right "state of attention."

In official discourses, terror awareness is first and foremost described as a critical detection skill that must always be practiced everywhere since, as McGovern 
(2011) states, "we can never know when we will be attacked" (58). Terror awareness therefore builds on an individual's acceptance "that the world is a dangerous place" (McGovern 2011: 58). It requires that individuals understand what "constitutes the normal, steady-state risk environment" in which we now live and accept that "living under threat" is the "new normal" (DHS 2018a: 14). Recognizing and accepting that the threat of terror is ever-present is a prerequisite for the successful practice of terror awareness (DHS 2018b; Flynn 2004; McGovern 2011). This acceptance is also referred to as the necessary "mindset" to practice terror awareness. According to McGovern (2011), only individuals who accept that the possibility of terror is an established part of everyday life will consciously employ awareness skills "every time they leave a location of relative safety" (59). Others might become complacent. Or they might "miss critical warning signs" (RAND 2005) because they lack the state of mind to interpret what they see, smell or hear within a framework of potential terror and dismiss it as "nothing" because they are unable to make a connection. They will be unable to decipher what philosopher Biesecker (2007) has called the "cryptology of terror." Signs of terror will—-to borrow Biesecker's words-remain "irreducibly opaque to the[ir] naked, unsuspecting, uninformed, and untrained eye" (159) because they refuse to acknowledge that "even-or especially-in circumstances in which we see nothing, something is likely taking place on the other side of a sign" (161). Thus, only those who learn to doubt their own perceptual experiences, accept that "we can never be certain of what we see" (161), and acquire the skill to read beyond the level of the immediate sign, will have a chance of becoming adept at terror awareness.

In addition to having the right mindset, what matters when it comes to proactively spotting and responding to situations of emergent terror is the right "state of attention." Existing research reveals that there are different states of attention. McGovern (2011), for example, differentiates between three states of attention: relaxed, focused, and heightened (59). In a "relaxed" state, an individual is alert to potential threats, but still able to engage in other activities, such as driving a car or having a conversation. When the individual perceives an anomaly in their surroundings or routines, he or she enters a state of "focused" attention. In this state, he or she becomes focused on the behavior, object or event that caught his or her attention because it seemed unusual or out of the ordinary. The individual now must decide whether the behavior, object, or event is threatening or non-threatening. If he or she decides that the anomaly is non-threatening, the individual falls back into a state of relaxed attention. If he or she determines the anomaly to be a potential threat, the individual then falls into the third state of attention: a state of high alert. This state allows him or her to take measures to avert or mitigate the perceived threat; it triggers action. Stewart (2010) describes pretty much the same three states of attention in his writings on terror awareness. However, he adds two additional states on either end of the spectrum: tuned out/daydreaming and panic/numbness. When an individual is daydreaming, he or she is completely unaware of his or her surroundings. When an individual is in a state of panic, he or she is unable to think clearly or function properly. Stewart (2010) also describes this latter state as one of "panic-induced paralysis." 
Both McGovern (2011) and Stewart (2010) suggest that "relaxed attention" is the appropriate state for terror awareness-that is, the state where an individual is comfortable and relaxed, but aware enough to notice anything or anyone in their surroundings that might cause trouble. This is echoed by the New Jersey Office of Homeland Security and Preparedness (NJOHSP 2012) in a participant guide for Terrorism Awareness and Prevention when it says: "Staying alert is NOT paranoia. Staying alert is simply being aware..." (11, original emphasis). Or, in the words of the DHS (2011c), "the whole purpose [of public awareness] is so that people will be alert, not alarmed." The goal is to allow them to react to an emerging reality of threat "with confidence, with resilience, and foresight, not with fear" (DHS 2011a). As McGovern (2011) points out, this level of awareness allows an individual to stay attentive for longer periods of time than the higher levels of awareness. It is not associated with the same level of stress or fatigue but allows an individual to quickly "dial up" to a higher state of awareness, if he or she detects anything out of the ordinary that could be potentially threatening (McGovern 2011).

\section{Components of Terror Awareness}

Once an individual possesses the right "state of mind" and is in the right state of "relaxed" awareness, the process of ascertaining situational terror awareness can begin. The process of ascertaining situational terror awareness is referred to as "situational analysis" (Matheus et al. 2003). There are three principle components to developing this kind of awareness: (1) perceiving and recognizing the emergence of a potentially dangerous situation by identifying its pre-indicators, (2) understanding what the perceived signs mean, and (3) understanding what to do with that information/knowledge. In the following, I address the three components—or, phases-of situational terror awareness sequentially, although it should be noted that in actual practice, they take place more or less simultaneously. Terror awareness involves a continuous "assessment-decision-action"-loop (Endsley 1995) that automatically replays with each evolving situation, that is, with each change in the "perceptive field of the individual" (LaFree and Birkbeck 1991: 75). It is an ongoing process. Finally, I would like to add a fourth component—one that acknowledges the role of something as fleeting and intangible as an individual's "gut feeling." I will call this the "affective" component. In practice, the process of ascertaining situational terror awareness is not always as rational and calculated as the previous three steps make it seem. As is known from policing research (Dunham et al. 2005; Pinizzotto et al. 2004), intuition based on experiential knowledge, the sense that something just "does not feel right," also plays a large part in determining whether an individual perceives of a situation as suspicious or non-suspicious, threatening or nonthreatening. This affective element also influences how an individual becomes aware of, interprets, and acts in a certain situation. What is more, as I will show, when it comes to civilian terror awareness, the governmental authorities are actively trying to harness this intuitive power. They are, in fact, encouraging civilians to "trust their instincts" and use their "gut feeling" to make decisions in moments of uncertainty. 
This component should therefore be added to our conceptualization of civilian terror awareness. But let's start from the beginning.

\subsection{The Spatial Component: Perception}

The first element of terror awareness is perception. Because civilians are considered to be "in the best position to spot... precursor activities, as [they] go about [their] everyday activities in [their] communities" (DHS 2011b), they are encouraged to pay close attention to and perceive of their surroundings in specific ways. At first glance, the term "perception" seems to have a special visual reference, as is indicated by the fact that civilians are asked to "be observant $[\ldots]$ attentive [...] watchful" (ODNI 2017). In fact, however, perception also includes all the other sensesin particular, hearing and smell. So, for example, civilians are not only asked to lend the authorities their "eyes" but also their "ears:" they are told to notice any "[s] parking, flashing, or popping sounds" coming from vehicles (SDPD 2019) or other "unusual noises" (SEAPD 2019) and to "overhear[] conversations in which individuals or patrons make unusual or alarming statements" (NYDHSES 2019a). They are also asked to pay attention to "unusual odors" (SDPD 2019) or "strange smells" (FEMA 2012: 39) and to report "[c]hemical smells or fumes that worry [them]" (LAPD 2019a). In short, they are asked to pay attention to a whole range of sensory cues. In De Anima, Aristoteles uses the term "perception" to refer to any thinking that is directed toward an apprehension of "what is" (cited in Scarry 2011: 9). Similarly, in discourses of terror awareness, perception refers to "the identification of the key elements or 'events' that, in combination, serve to define the situation" (NRC 1998: 173) through whatever sense is available. In the initial phase, the aim for terror-aware civilians is to simply "take inventory of what's happening around [them]" (NCDP 2018). The aim is to collect as much perceptual information as possible through sensory observation so that the individual may be able to assess "what is." Individuals must not yet selectively focus on certain persons, behaviors, events, or objects. Instead, they must take note of all the elements that are present in their perceptive field, that is, of everything that is rendered intelligible through all of the senses at a certain location and moment in time.

While most people go through the day without even noticing everyday events, terror-aware civilians are told to pay careful attention to "their surroundings" (DHS 2018a) and "what is going on around [them] at home and while [they] are away" (City of Wheeling 2019). They are encouraged to "be vigilant and aware of surroundings in any environment-in crowds, at concerts, in schools/campuses and in everyday life" (City of Chicago 2019, emphasis added). After all, the "dangerous situation" to be governed is assumed to emerge from and within the perceptual field of the individual at any given point in time (LaFree and Birkbeck 1991: 75). There are a few locations, however, in which individuals are asked to be especially vigilant. They include (see, e.g., DHS 2018b: iii, 1; MPDC 2019):

- Government buildings

- Religious facilities 
- Amusement parks

- Sports/Entertainment venues

- High-rise buildings

- Mass-gathering locations_-parades, fairs, etc.

- Schools

- Hotels

- Theaters

- Shopping malls

- Bridges

- Public transportation

In any of these locations, terror-aware individuals must always ask themselves: What do I see? What do I hear? What do I smell? What do I feel?

This list shows that the authorities are encouraging situational terror awareness, especially in places that they consider to be preferred targets by terrorists. According to the DHS (2018b), these locations are especially at risk because they "are easily accessible to large numbers of people and ... have limited security or protective measures in place" (iii). In these locations, individuals must therefore constantly remain in a state of alert and be observant of what is going on around them. On its website, the Emergency Management Agency of the state of Maine (MEMA 2016) describes it with the following words:

Be alert to anything in public places, your neighborhood, workplace surroundings or along your commute route. (emphasis added)

"Anything" includes people, objects, their locations, motions, sounds, actions, routines - the entire setting (see BJA n.d.). Significantly, it also includes things that may not be immediately visible or that might be concealing a source of threat. Terror awareness requires individuals to also pay attention to what Goffman (1971) calls "lurk lines," that is, lines that demarcate zones that are beyond or behind one's line of sight. Terror-aware individuals routinely identify potential hiding places for persons and objects - such as doorways, driveways, or alleyways-because they understand that, for example, "[d]im hallways and corners or trash bins that aren't regularly emptied" constitute "locations where [terrorists] can leave objects and equipment undetected" (MDOT 2019). Accordingly, they take note of any objects, walls, or barriers that might be obstructing their view, such as cars or pillars, and reflect on the things they might not be seeing. And finally, because these individuals not only aim to preemptively become aware of any emerging situation of terror but also seek to be prepared for the possibility that such a situation cannot be prevented, they routinely look for the locations of emergency exits, staircases, pay phones, fire alarms, fire extinguishers, and any spaces that can provide shelter in case of an attack (see, e.g., COEM 2018; NCDP 2018).

The risk at this stage, of course, is that individuals experience information overload and a total visibility that, ultimately, amounts to blindness; for it is a simple fact that where everything is overexposed, one sees nothing at all. Situations may last only a few seconds. There might also be "many different things... happening simultaneously" (Goffman 1974: 9). This can quickly become overwhelming. Yet, 
amidst the cacophony of sounds, sights, and smells present in modern cities, terroraware civilians must identify those pieces of information that may indicate a situation of potential danger is about to unfold. Therefore, they must be able to "make sense of a situation without being overwhelmed with information" (Ulicny et al. 2013: 87). Once they have understood that any opportunities for terror "lie hidden in the ordinary details of everyday life" (Clarke and Newman 2006: 10), they must somehow filter the enormous flow of visual, auditory, and tactile information they are collecting at any one point in time. They must learn which details to focus on and which ones to discard, what elements to selectively pay attention to. After all, "[a]ttention 'presents' to consciousness an awareness of what is being perceived" and enables individuals "to make judgements and decisions" (Hoffman 2015: 74). Hence, to make sense of what they are perceiving, terror-aware individuals must learn to differentiate signals from noise in order to be able to identify the "precursory signs of what threatens to happen" (Derrida 2003: 96). Only then will they be able to successfully play their role in preventing future acts of terror. "By learning what to look for, you can aid law enforcement officials in protecting the homeland," a flyer provided by the Bureau of Justice Assistance (BJA) to local police departments instructs the public (SPD 2019, emphasis added). And, on its website, the DHS (2019a) explains that it is "by learning the indicators of suspicious activity" that individuals can "help keep their communities safe."

So how can civilians eager to skillfully master terror awareness learn which signs to focus on? What are the "indicators of suspicious activity" the DHS refers to? A plethora of flyers, brochures, and other written materials are currently available that teach the public about what security scholar Aradau (2015) refers to as the "epistemologies of the clue" (22). They constitute a form of public pedagogy that instructs individuals where to look, what to see, and what not to see. They modulate public attention by giving certain things to be seen and, implicitly, rendering others invisible. They produce specific visualizations of potential future threats and render them socially available. They provide visions and narratives that give the suspicious imagination substance and form. What all these pedagogical materials have in common, is that they teach the public to sort their sensory impressions by applying a normative visual filter that differentiates between ordinary/out of the ordinary, usual/unusual, and normal/abnormal. While closely observing their surroundings, individuals are told to look specifically for behaviors or objects that do not fit the expected context of the situation. "All you need to do," the NJOHSP (2012) informs civilians, "is pay attention to those activities and people who seem out of place" (11). Elsewhere, civilians are told to focus on anything "atypical" such as "behavior and activities that are unusual or out of place for the situation and that appear to be suspicious" (SPD 2019; see also BJA n.d.). And the DHS (2017), for example, encourages terror-aware individuals to take note when:

A vehicle is parked in an odd location, a package/luggage is unattended, a window/door is open that is usually closed, or other out-of-the-ordinary situations.

Other examples of indicators or "clues" include "individuals who don't fit into the surrounding environment" (DPD 2019) or are "in places where they do not belong" (SPD 2019), individuals "wearing clothing inappropriate for the current weather" 
(NYDHSES 2019a), and individuals "who [are] in an area or doing something that is not normal" (HPD 2019). They include "unusual noises" (SEAPD 2019), "abandoned parcels or other items in unusual locations" (SEAPD 2019), unattended items that are "incongruous to the location" (APTA 2012), individuals who are "paying attention to facilities or buildings beyond a casual or professional interest" (DHS 2019a), and individuals who articulate "unusual requests for information" (SPD 2019).

These examples further illustrate that any "out-of-the-ordinary signals that deviate significantly from an established status quo" (RAND 2005: 1) seem to warrant focused attention by terror-aware individuals. They show that "suspicious," in the context of terror awareness, seems to be any "occurrence that is out of place in your neighborhood...," as a local police department notes on its website (BPD 2019); it is anything "out of the ordinary for the time, place or circumstances" (APTA 2012) under which an observation is made. These "out-of-the-ordinary signals" are the specific elements in an environment that terror-aware individuals are asked to identify and take note of - the underlying assumption being that anything "unusual" or "atypical" might be a sign for the individual that they are in the midst of an impending, potentially dangerous situation. Any unusual change in status quo is the trigger that requires terror-aware civilians to take a closer look, to shift into a state of focused attention, so that they may differentiate potentially threatening situations from harmless situations (see also Hollywood et al. 2004: 7). Future terror is made tangible in the present through this kind of reading of social reality for signs of anomaly or "out-of-the-ordinariness," that is, for those things that defy predictable expectations (Boltanski 2014: 9; see also Goffman 1971, 1974). Normalcy, by contrast, is the "non-event" where nothing unusual happens and individuals can remain in a state of relaxed awareness.

\subsection{The Cultural-Normative Component: Comprehension}

The second component of situational terror awareness is comprehension. Terroraware individuals must be able to understand and interpret correctly what it is they are perceiving. Not all sensory information is equally relevant. Only some of the information gathered will be tactical information and help the individual gain "important knowledge that may forewarn of a future attack" (DHS 2019c). As we recall from the definitions of situational awareness presented earlier, to "develop a composite picture of the situation" (Fracker 1991), it is important to understand the elements in the environment, their meanings and how they relate to one another (see Endsley 1995; Vieweg 2012). This means that, to acquire terror awareness, individuals must be able to assess, integrate, and structure the sensory information gathered from their surroundings so that they can transform it into knowledge that represents an accurate and holistic picture of the situation and its significance (Harrald and Jefferson 2007: 3; see also NRC 1998; Vieweg 2012). Being able to put together such a holistic picture is important because it will enable the individual to quickly assess whether the unfolding situation is one of potential danger and make decisions accordingly (see NRC 1998: 173). In situations of terror emergence(y), action 
must immediately follow perception. Hence, the goal at this stage is to enable rapid decision-making, and the significance of any information gathered in the previous stage must be assessed with this goal in mind. After all, "very subtle observations [] can make the difference between interceding and stopping a dangerous act, or not" (FEMA 2012: 39).

At this point, it becomes clear why the authorities are asking not simply for an "alert" citizenry, but also an "informed" one. As notes the DHS (2011c): "the $e d u$ cated participation of individual citizens is an important part of [our] success." In order to determine whether an unfolding situation is potentially dangerous or not, individuals need two kinds of knowledge. First, they need knowledge about their own communities and, second, about the nature of the potential threat. Situations consist not solely of the immediately perceivable ensemble of different objects, persons, and events in a location and at a moment in time; the contextualities of this ensemble also matter (see Dewey 1938). As part of a situation, the various elements-objects, persons, and events-and their interrelations are always experienced and judged in connection with a contextual whole (Dewey 1938). Contextual knowledge-either immediately present in the situation or from prior experienceguides perception (see Flach 2015; Afdile et al. 2019). It influences what observers notice, how they do so, and how they make sense of what they are seeing. So, to understand what constitutes "atypical" or "out-of-the-ordinary" behavior or objects in a specific setting, terror-aware individuals must have good knowledge of what is considered "normal" in their everyday surroundings and communities. This experiential knowledge contextualizes the "atypical" and renders it visible. It also ensures familiarity with culturally specific behaviors and routines (see FEMA 2012). It becomes a safeguard that "normal cultural behaviors are not mistaken for potentially suspicious activities" (Wasserman 2010: 20). But beyond familiarity with their communities and neighborhoods, to understand whether any "unusual signs" are potentially relevant to the possibility of terrorism, aware civilians must also be familiar with terror's identifiable precursors, its pre-incident indicators.

"Cues to danger... are not self-evident or self-explanatory; individuals may fail to discern or properly interpret cues.... The ability to detect, interpret, and respond to cues is a skill that must be learned, and it is acquired through experience with an environment," Warr notes (1990: 892). According to him, it is an individual's "acquired experience with an environment that determines what [he or she] senses as alarming" (892). It follows that terror-aware civilians must develop familiarity with and "know the normal routines" (NYDHSES 2019b) in their everyday surroundings. And, indeed, "[k]nowing neighborhoods and knowing what makes sense and what doesn't," as the DHS (2011c) phrases it, is a crucial aspect of developing terror awareness. "Understanding these routines will help you spot anything out of place," the New York State Office of Homeland Security (NYDHSES 2019a) explains. The National Strategy for Homeland Security of 2007 (WH 2007: 19), similarly, suggests that to be able to recognize "unusual signs," individuals must develop a "baseline understanding of their [...] environments - the people, the geography, and the daily and weekly rhythm of activities and events," because it is only "[b]y understanding trend lines, [that they] can better identify anomalies and deviations that could indicate terrorist activity." And according to the Federal Emergency Management 
Agency (FEMA) (2012), ordinary citizens are "the individuals most likely to identify suspicious activity in their neighborhoods," because they are "likely to take the same route to work each day," to "frequent the same stores, parks, and public areas," and to "recognize their neighbors and cars on the street" (3). This means "[t]hey know when something is out of place" (3, emphasis added).

Here, routines are presented as translating into an understanding of what is "normal" in a specific environment. Terror-aware civilians are asked to be perceptive of these routines and learn what they are in their "neighborhood, community and workplace" (NYDHSES 2019b). They are asked to familiarize themselves with their communities, track their characteristics, and establish expectations for what is "normal" in any given situation. For it is only when they know what a "normal" situation looks like that they will be able to recognize the slight deviations or changes that might indicate an "unusual" or "out-of-the-ordinary" situation, and thus a potentially dangerous one. As notes the New York State Office of Homeland Security (NYDHSES 2019b):

We have the opportunity to identify individuals with malicious intentions before they are able to cause damage. While preparing for an attack they may conduct themselves in ways that do not match the usual pattern of activity found within our daily lives, which makes them stand out from others. [Therefore k]now the routines of your community, always remain alert and aware of what is going on around you and take what you hear seriously.

By studying the routines in their neighborhoods, communities and workplaces, individuals can develop cognitive schemata_-or, mental images-of their surroundings that help them to make sense of and organize future sensory information (Alpert et al. 2004: 1-8; see also Brehm et al. 2002). Based on these learned "mental images," they can then form suspicions when they encounter a situation they did not expect or anticipate. They can "see things that are out of line from the norm" (FEMA 2012: 39).

However, not all "atypical" or "out-of-the-ordinary" observations are necessarily relevant to terrorism. To be able to recognize which observations matter, the authorities therefore suggest that terror-aware civilians acquire knowledge about the nature of the terrorist threat and its identifiable precursors. "Familiarize yourself with the signs of terrorism-related suspicious activity," the DHS (2019d) advises. The authorities are encouraging individuals to educate and inform themselves about the so-called "terrorist attack cycle" and any known pre-incident indicators ("compiled from a review of terrorist events over several years," LAPD 2019b, c), that is, any suspicious activities that can possibly be related to terrorism. All the while, the emphasis lies on the "how" and not the "who" of terrorist activity. Terror is thought of as a process that moves through different stages, such as target selection, preattack surveillance, planning, rehearsal, execution/attack and, finally, escape/exploitation (ODNI 2019). In each phase, the actors are assumed to leave behind traces or "clues" as to their activities and intentions. Terror-aware individuals can learn to spot these "clues." "Any of, what we call, these "precursor' activities might be observable [...] by a vigilant member of the public," the DHS (2019e) informs the public in a public service announcement. These "clues" render the future potentiality 
of the threat visible and knowable in the present (see also Martin 2018). The DHS claims that individuals who are familiar with these "signs of terror" can see and identify the infinitesimal traces of an adversary in their everyday lives. This in turn will allow them to take appropriate actions to preempt or mitigate an impending attack. At the same time, the authorities caution that "[n]o one indicator alone necessarily indicates suspicion, it's normally a combination" (DPD 2019). Sometimes "some of these indicators on their own may appear to be innocent" and it is only when an indicator is "combined with other indicators" that a picture of potential attack planning emerges (ODNI 2017). Therefore, while "one or more of these indicators could signal suspicious activity, [...] each situation must be independently evaluated" (ODNI 2017). And careful attention must be paid to repetitions and possible patterns.

\subsection{The Temporal Component: Projection and Decision-Making}

The third component of terror awareness is projection. Projection is a temporal component. From the literature on situational awareness, we know that it means developing an understanding of and making predictions about what might happen in the near future (NRC 1998: 173). It means looking ahead to-or, anticipating-the actions that people and things in a situation can possibly take (Stewart 2012). The focus here lies not on the present situation, the "what is," but on "things to come" (Anderson 2010: 229). In this phase, terror-aware individuals are told to imaginatively project the movement of people and objects forward in time, scan their potential lines of action, and track their potential future paths. With Aradau (2010: 4), we can understand this part of terror awareness as an attempt to own, or "inhabit," an as-of-yet-unknown-but-potentially dangerous future. Through projection, terroraware civilians can attempt to "grasp and handle" (Focuault 2007) a future situation, which is still formless and highly contingent. They can try to turn an essentially still indeterminate situation of becoming into a situation that, although it can never be fully known, is determinate enough to enable decision-making and action. They can do this by perceiving of the elements in their environments not simply as they are right now, but also in terms of what they might become-by asking themselves "what if" and imagining possibilities. This projective element is important because civilians must ultimately act in response to the projected future (see Wickens 2015: 93). Only the projected future counts, because by the time their response plays out, the current state of things will have already passed, and the situation will be a different one. Based on knowledge about the nature of the threat, terror-aware civilians therefore have to make sure they understand and recognize how precursor activities connect to the bigger picture. "Even if you think your observation is not important, it may be a piece of a larger puzzle," they are told (NJOHSP 2019). Statements like these teach the public that there may always be more to what they are seeing; that they need to "connect the dots" and learn to look beyond surface appearances so that they can see things in their capacity as signs of impending terror.

Reading elements in the environment against a normative template and as indicators of a potentially threatening future is distinctly anticipatory. Individuals are told 
to be on the lookout for so-called precursor events, that is, events that "could indicate terrorism or terrorism-related crime" (DHS 2019b). The language used by governmental and security officials is possibilistic: it is only possible that these observable behaviors are related to terrorist activity and, thus, constitute harbingers of a dangerous future, but they could also be completely innocent. When a person spots what could be a precursor activity, no attack has occurred yet. It is unclear at this point whether the observed situation will evolve into to a threatening situation. It may or may not be the case. This means that when terror-aware civilians set their sights on certain persons or objects, their "dangerousness" is still nothing but a potentiality. The threat has not yet taken definitive form; the situation is not yet dangerous. As a governmental technique, terror awareness targets this in-between time-space, the phase immediately preceding an act of terror. A Counter-Terrorism Guide for Public Safety Personnel (ODNI 2019) describes it as such: "Awareness and vigilance are crucial to identify behaviors that can lead to a violent act" (emphasis added). Terror-aware civilians are requested to direct their attention toward persons and objects that carry within them a potential for violent mobilization: "Several behaviors, when taken in context, can indicate radicalized individuals are mobilizing-preparing to engage in violence...," the Guide notes (ODNI 2019). Terror-aware individuals will only be able to recognize this mobilizing force; however, when they have in mind different scenarios, it could lead to a repertoire of "imagined situations" (Anderson 2010) that could evolve from the present constellation of people and things, at least one of which is a dangerous one. Otherwise, they will not be able to mentally map the mobilizing force's projected path, its trajectory toward violence. They will only see what a person is doing or what an object is right now: someone taking a photograph in the Mall of America or a bag-left-behind underneath a seat on the subway. What they will not see is: a person conducting reconnaissance activities in preparation of an attack or an explosive device disguised as a bag. As is the case with actual puzzles, where a certain piece belongs is difficult to determine and can be daunting to figure out, unless one knows what the final image is supposed to look like.

Kass et al. (1990) argue that for good situational awareness, individuals must "be able to extract and integrate the relevant cues" (1353). In the context of terror awareness, the cues must be integrated imaginatively into a bigger threat picture, a picture of the threat as it may unfold. However, in and of themselves none of the indicators listed on governmental websites or in publications by security and law enforcement agencies are definitive proof that an act of terror is about to transpire. In fact, the authorities themselves acknowledge that "some of these activities could be innocent" (DHS 2019b). And although some of the behaviors listed are criminal, such as using a false ID, they do not necessarily indicate terrorist intent. The signs are highly ambiguous. Sometimes what appears completely innocuous is actually a sign of impending terror. So, for example, a flyer published by the New York State Division of Homeland Security and Emergency Services (NYDHSES 2019b) notes: "Those who wish to do us harm walk among us, often in plain sight." The flyer suggests that those who pose a threat, may remain unseen — or, better unrecognized-by us, but yet, the danger is there. At other times, what appears suspicious is actually innocent. In 2009, for example, a University of Washington professor was frisked, handcuffed and detained for taking photographs of power lines. It turned out the 
photographs were part of an art project (ACLU 2009). What constitutes "suspicion" is kept deliberately vague in discourses of terror awareness to cope with the uncertainty and unpredictability of dangerous situations. But it also makes it difficult for individuals to determine at which point ordinary elements in their surroundings are becoming signs of an emergence(y) situation. How then are civilians able to make security-relevant decisions, to assess what is about to happen in the here and now and respond accordingly?

To nevertheless enable decision-making in these emergence(y) situations, the authorities are telling terror-aware individuals to embrace the element of uncertainty, as it can never be fully resolved until it is too late, and the threat has materialized. Instead of waiting for certainty, the DHS (2019e), for example, proposes that suspicions of terror-aware individuals should already be roused "when [they] experience [that] moment of uncertainty." Uncertainty, in discourses of terror awareness, is presented not as a problem, but as part of the solution. It is an opportunity to prepare for the possibility of terror. It is the sensual impulse that can trigger (self-) protective action. The potential for controlling a potentially dangerous situation at its point of inception is located precisely in this "moment of uncertainty." For one, it indicates that things are not "as usual" (otherwise, one would not feel uncomfortable) and, secondly, it signifies that nothing has been decided yet. The dangerous situation has not materialized yet; it is still lying indeterminately in the future. Through anticipation, the projected path of this future can still be intercepted and altered. By thinking proactively and making the decision to act even without certainty, terror-aware individuals can retain control over the situation's emergence and foreclose some of its potential unfoldings. A security video created by the Federal Transit Administration (FTA 2007) called "The Mark" drives home this point. The video shows a group of terrorists planning an attack on a transit system. Several of their attempts are thwarted because vigilant transit employees noticed and reported their preparatory activities. The video, thus, demonstrates how anticipating a potentially threatening situation when faced with suspicious and unusual circumstances could ultimately mean the difference between life and death (see also APTA 2013: 6). What is more, in the final scenario, the attack is successful, and a poisonous gas is released inside a subway car. However, a nearby station agent immediately realizes what is going on and initiates the appropriate emergency response. Here, the video shows that terror-aware individuals are not only able to preempt dangerous situations, but that they can make sure they are not caught "off guard"- -or, worse yet, paralyzed into fear-by finding themselves in a dangerous situation they never saw coming. This is a point I will come back to again later, in the final section.

\subsection{The Affective Component: "Gut Feeling"}

The final component of civilian terror awareness I would like to discuss is the affective component. This aspect is missing from the more technical definitions of situational awareness presented earlier (or is at least not rendered explicit), but it is an important part of what constitutes terror awareness. Indeed, when it comes to terror awareness, the authorities are routinely asking members of the public to "trust their 
instincts" or "gut feelings" and rely on this specific form of pre-conscious, pre-attentive, and implicit knowledge to make security decisions. Whereas the risk-based threat assessments that are part and parcel of algorithmic security practices revolve around the pretense of "objective facts," terror awareness with its emphasis on identifying dangerousness implies a subjective assessment or "sensing" of degrees of threat (see Floud 1982). The Police Department of Hilliard, Ohio (HDP 2019), for example, informs residents:

Suspicious behavior is sometimes difficult to define, but it is one of those things that most people say they "know it when they see it." It is something that is out of place, not quite right, or just makes you feel "weird" about it.

Similarly, the Arizona Counter-Terrorism Information Center (ACTIC 2019) urges members of the public: "Do not ignore your feelings of uneasiness about a person or circumstances you may encounter." FEMA (2012) tells them to rely on their "personal instinct" (2) and the American Public Transportation Association (APTA 2012) advises them to be suspicious of anything that "raises feelings of wariness or distrust" (8). Finally, in a report, the Bureau of Justice Assistance (BJA) (n.d.), together with the National Sheriffs Association (NSA), defines "suspicious" as anything that "looks out of place" or "feels uncomfortable" (21). These examples show that terror awareness is routinely presented as involving a certain degree of visceral experiencing - something akin to a "sixth sense." They suggest that staying terror aware and making decisions about potentially dangerous situations clearly involves some kind of affective judgements that are formed by feelings, moods, and intuitions.

Terror-aware individuals are asked to permanently remain in a state of relaxed awareness, waiting and looking for signs of an unfolding emergence(y) situation. Bissell (2007) has argued that such "bodies-in-waiting" are characterized by an "enlivened corporeal sensibility" (284). He describes them as "highly attuned to their immediate environment and themselves" (ibid.). If we think of terror awareness as "waiting-for-the-next-attack," then, it becomes possible to see it as involving not only situational but also corporeal (self-)awareness. Attention is directed not only outwardly to "suspicious" encounters, but also inwardly to the vigilant body itself. Terror-aware civilians are told to stay attuned to the felt presence of a menacing future, which, in the examples I have cited, manifests itself as "uncomfortable" feelings. These felt intensities constitute a form of bodily knowledge that can help them assess a situation and make security decisions without thinking (see Damasio 1995: 173; Connolly 2002: 27). Damasio (1995) likens them to an "automated alarm system" (173) that alerts a body to potential harm and helps an individual prioritize their responses. He argues that they "assist the deliberation by highlighting some options (either dangerous or favorable) and eliminating them rapidly from subsequent consideration" (1995: 174). In short, felt intensities enable individuals to rely on their reflexes rather than conscious thought in moments of uncertain danger. This is important because, as a flyer from the Metropolitan Police Department in Washington, DC, states (cited in FEMA 2012: 40): "Emergencies can occur quickly and without warning." When it comes to terror awareness, time is thus of the essence. Terror awareness is a protective practice in time-sensitive contexts where decisions 
must be made in "real time." It makes sense, therefore, that individuals are encouraged to listen to their "gut feelings" and "intuitions."

A threat is a rather diffuse, felt intensity; it is nothing concrete yet but exists primarily as an affect (Massumi 2013). In the relevant academic literature, "affect" is described as a contested and difficult-to-define term. Generally, however, it is said to refer to a form of pre-conscious, pre-personal incitement, to-as one of the leading scholars, Brian Massumi (2015), describes it-the "capacity to affect and be affected." Affect forms during an encounter-with another human being or an environment (Kaufmann 2015: 104). It acts on and within the body, constitutes it, and, at the same time, moves it toward action. In studying preparedness exercises for emergency response, Anderson and Adey (2011) have found that threats impress upon bodies through affect, "whether that is in a vague atmosphere of unease or in a punctual moment of heightened apprehension" (1096). "Threat," they argue, becomes "the future quasi-cause for an affective change in the present" (1096). When we feel threatened and uncomfortable, perhaps even fearful, all we can say is that something about a particular situation - the ensemble of the various elements in our immediately perceivable environment-is beginning to move or affect us. We are not quite able to pinpoint what it is yet at this point. If we knew, we could act. But for now, our discomfort is nothing but a vague feeling, a sense of unease, that arises from the constellation of people and things around us (see also Adey 2014: 835). What our body is responding to remains at a pre-subjective, pre-conscious level; it still escapes articulation and is nothing but an "ambient sense of things out of sorts" (Adey 2014: 834). It is an alteration of the mood or atmosphere in a situation that makes something strange or unusual present through the diffuse perceptions and sensations it gives rise to (see Adey 2014; Kaufmann 2015). And it is precisely this ability to be moved and affected (negatively) by a situation that the homeland security authorities are tapping into with their injunctions to "be aware" and attuned to things that do not "feel quite right."

Awareness courses, training materials, informational brochures, books, as well as official government documents - they all place considerable emphasis on encouraging the public to "take ownership of, and act upon, feelings of suspicion" (Coaffee and Fussey 2015: 94). To see and recognize signs of the emergence of a potentially dangerous situation, the authorities are routinely asking civilians to act as embodied "sensors" by staying attuned to the way surrounding objects or people move them. As the DHS (2019e) postulates:

It's when you experience a moment of uncertainty. Something, or someone's behavior that doesn't seem quite right. These are the moments to take a pause. Because if something doesn't feel right, it's probably not. [...] We trust our instincts. Just like you should.

Statements like these foreground affective experiences as a mode of legitimization for decision-making and action in situations that are possibly becoming-dangerous. Civilians are not asked to assess whether their feelings of discomfort are warranted and the signs they are perceiving are truly related to the possibility of terrorism. If it "doesn't feel right," they are told, it is safe to assume that "it's probably not" (DHS 2019e). Any sense of things out of sorts thus activates and legitimizes 
certain responses (from removing oneself from the situation to alerting the authorities). Fleeting, sensorial impressions are considered enough to establish "suspicion" and, ideally, trigger an immediate "protective reflex" (Giroux 2008). This is exemplified by a poster the Massachusetts Bay Transportation Authority (MBTA 2014) has published in Boston, which reads: "Instincts tell you to do something? Do something!" Decisiveness is valued, deliberation is not. After all, "[i]t's always best to err on the side of caution" (NJOHSP 2012: 45). The surest protection from the contingent forces of indeterminate terror is action: if there really is a threat, then action can prevent it. If there wasn't one, it could have been there potentially. Fortunately, however, by preempting the possibility, it can be ensured that the threat will surely never materialize. "It may be nothing, but it's better to be safe than sorry," the DHS (2009) argues. Guided by this logic, terror awareness enables quick decision-making under conditions of complexity and uncertainty because there is no need to wait until the threat has fully formed and begins to materialize.

\section{Civilian Terror Awareness as Preparedness/Resilience}

In his book Vigilance: Staying Guarded in a Dangerous World, Detective Joseph Mayberry (2018) summarizes terror awareness as "doing the miniscule, subtle things preemptively to prevent a problem or situation from occurring before it happens" (11). And in the previous section, I have shown how terror awareness plays out as an anticipatory practice. But in discourses of homeland security, the term "(terror) awareness" denotes more than just an active lying-in-wait-and-looking-outfor-signs-of-terror. Terror awareness is discussed also as a technique for civilians to achieve situational readiness-or, preparedness. To phrase it differently: terror awareness is presented not simply as a proactive self-defense mechanism but also as a "response-ability" (Berkowitz 2009) of ordinary citizens in the face of an everpresent threat that cannot always be prevented. It is, as the DHS (2011a) emphasizes and I have mentioned earlier, about "foresight" and "resilience." Terror awareness is a security technique that covers the situations before, now, and after an event of terror. Before I conclude this paper, therefore, it is important to briefly discuss this element as well-especially because it also provides us with further insight into the bodily posture terror-aware civilians are expected to adopt and the kind of subject they are ultimately supposed to become: a "citizen-soldier" (Orr 2004) on the American home front.

In discourses of terror awareness, the time-space in the aftermath of an event of terror is equally as important as the one prior to it. In a training brochure, the Colorado Office of Emergency Management (COEM 2018) acknowledges the post-evental aspect of terror awareness when it writes: "Being aware is being prepared." And it goes on to explain that situational terror awareness is about learning "to successfully recognize, report, and react to potential terrorist incidents" (emphasis added). The DHS (2018b: 2-3) similarly notes:

A public with a basic knowledge of indicators of suspicious activity, how to report them, and what to do in life threatening situation (e.g., "Run - Hide 
- Fight" in the face of an active assailant; basic first aid for traumatic injuries) can prevent attacks before they occur and dramatically lessen the consequences of attacks that do occur.

These quotes indicate that terror awareness is about more than just the timely recognition of emerging situations of terror. It also involves specific ways of responding to them and mitigating their potentially catastrophic effects. Terror awareness is simultaneously a proactive and reactive practice. It addresses both the initial "bad surprise" associated with emergency situations and the complex aftermath of their occurrence. In fact, time and again, it is presented by the authorities as a key mechanism for empowering civilians as potential targets of terror and making them more resilient by preparing them for when things go wrong.

According to the DHS (2018b), the objectives of enhancing terror awareness are threefold: (1) fostering recognition among the general public of the contemporary steady-state threat environment; (2) empowering the general public to manage this threat by educating them on how to recognize and report suspicious activities; and (3) preparing them for the possibility that preventative efforts fail and a terror attack does occur (16, emphasis added). "While we cannot eliminate all of the threats we face," the DHS (2016) has argued elsewhere, "we can improve our chances of surviving..." From its perspective, this can be done by teaching members of the public how to be aware, prepared, and...fearless. Fear is recognized as a natural response to the threat of terror: "It's natural to be afraid of terrorists and their acts," the Colorado Office of Emergency Management (COEM 2018) acknowledges. (And in the previous section I have shown that sensations of fear, as affective responses to subtle signs of danger, are actively harnessed by the authorities as part of their emphasis on anticipatory awareness.) But in discourses of homeland security, fear is also interpreted as a weakness, as something the adversaries are seeking to exploit: "It's also our fear upon which terrorists feed. Terrorists use our fear as a weapon to achieve their political and social goals" (COEM 2018). Consequently, "[k]nowing how to handle fear [becomes] a vital part of addressing terrorism," as a Training Guide on Creating Vigilant, Prepared, Resilient Communities for Homeland Security published by the Western Community Policing Institute (WCPI 2009: 46) postulates.

According to official narratives, "terrorists" are seeking to disrupt the American way of life by causing fear or panic, as well as intimidating and demoralizing the American public (NJOHSP 2012: 4-5). They are considered successful when they achieve these goals. "Terrorism is only successful when it disrupts the lives of the people whose government is targeted," the San Diego Police Department (SDPD 2019), for example, states on its website. To ensure that life continues "as normal" despite the persistent threat of terror and to refuse to be negatively affected, therefore, becomes an essential means for countering terror. In line with this reasoning, terror-aware civilians are encouraged to not be afraid-or, just afraid enough to "if something doesn't seem quite right, say something! Do something!" (City of Henderson 2019). They are expected to know how to take precautions against their own potential victimization, be self-reliant, and able to "bounce back" should the anticipated emergence(y) situation come to pass. This is because they have readily adopted the scenario of a potentially terrifying future as their rationality for 
vigilant and aware self-government in the present. They have accepted the government's premise that "terrorist threats are real and dangerous" (FEMA 2012: 2) and that "law enforcement officers cannot [manage them] alone" (FEMA 2012: 6). They have understood how to be "more active partners and powerful assets" that can help the authorities "to prevent and prepare... [for future acts of terror]" (DHS 2009). The DHS (2011b) has repeatedly postulated the need to create communities that can "take care of themselves." It has encouraged the public to think of themselves as proactive defenders of their communities ("It takes a community to protect a community," DHS 2018c) and "force multipliers" (FEMA 2012) for the authorities, rather than as potential victims. And terror-aware civilians are rising to that challenge.

Terror-aware civilians cannot be caught off-guard, because they are always alert and have anticipated different emergency situations. They are able to move beyond the fear-inducing effects of terror and make effective security decisions that will allow them to recover quickly and help others. Research from the aviation sector has shown that, even under exceptional circumstances or when startled, situationally aware individuals can remain calm, quickly assess the situation, and respond appropriately (see Martin et al. 2015; Thackray 1988). The FTA's (2007) security video "The Mark," which I discussed earlier, suggests the same holds true for terror-aware individuals. In any scenario shown, the transit employees, who have been trained in terror awareness, are acting courageously_not only when being questioned aggressively by "terrorists" in the process of carrying out reconnaissance activities, but also after an attack has been perpetrated (at one point in the video, a member of the "terrorist" group, frustrated by their numerous unsuccessful attempts at preparing for an attack, observes wearily: "the situation has changed," "they have been trained"). The video thus suggests that there is less chance for terror-aware civilians to become despondent or dispirited in the face of adversity because they are not helpless. It shows them not as a "liability to be protected" (DHS 2009), but a "critical resource" (FEMA 2012). It shows them as "active participants" (AZDOHS 2019) in the maintenance of homeland security. And this resilience makes them, as Zuhdi Jasser (2011), President of the American Islamic Forum for Democracy (AIFD), has told the Judiciary Committee of the US House of Representatives at a hearing: "one of the most important fronts, if not the most important front, in this battle" against terror (original emphasis).

The militarized language used here indicates that, by calling on the public to act in a situationally aware manner, the authorities are attempting to-gradually-restructure individual perception according to a logic of (urban) warfare. By calling on the public to always "be aware and prepared," they are trying to normalize and "invisibly" embed a military logic into the mundane routines of ordinary citizens and thereby to make the "war on terror" immanent to everyday life. They are also attempting to re-constitute civilians as fearless and resilient "citizen soldiers" (Orr 2004) who, through their embodied and situated practices of watchfulness and ad hoc decisions about "friend" or "enemy," are continuously enacting the boundaries of an American "homeland" whose formal borders have been rendered obsolete by a threat that is always already incubating "in our midst" (see Jenkins et al. 2014). They are appealing to a powerful imaginary of the "soldier" as a loyal, strong, courageous and self-sacrificing hero (Foucault 1977: 135), while asking civilians to 
re-adjust their day-to-day routines and activities to meet the demands of this "war" and, thereby, to uphold the existing order which is perceived to be under threat.

In this regard, discourses of terror awareness position civilians as more than law enforcement's passive "partners," merely reporting observed deviances and then stepping back to let the authorities do their job. Rather, with their perceptive powers trained to recognize the taut incipiency of terror, their minds adapted to "withstand" the horrors of potentially catastrophic attacks, and their bodies able to safely maneuver public spaces as tactical spaces, they are, in the words of former Republican US Representative Trent Franks, constituted as the nation's "most effective terror-fighting weapons" (2011: 2). And, indeed, an awareness poster published by the New Jersey Office of Homeland Security and Preparedness (NJOSP) tells citizens precisely that. It reads: "Our most effective weapon against terrorism is you" (cited in McAneny 2008). Through this militarized language, civilians are turned into aware and resilient urban "warriors" (O'Malley 2010) who are defending their homeland with courage and strength by never giving into fear, complacency or fatigue.

\section{Conclusion}

In some respects, there is nothing substantially new about the idea of mobilizing the "eyes and ears" of the American public as a resource for identifying and governing perceived threats. As American sociologist Goffman (1971) has noted in his essay "Normal Appearances," human beings naturally engage in "a constant monitoring of what surrounds" (238) to identify and recognize potential dangers. This natural tendency to "read situations" (Goffman 1971) for signs of threat has been harnessed by government and security officials at various points and for varying purposes throughout the 20th century (see Greenberg 2005; Reeves 2013; Stieglitz 2013). In the form of neighborhood watches, for example, the enlistment of civilians has been a long-time staple of American community policing (see BJA n.d.; Docobo 2005; Greene 2011). But it has also played an important role in civil defense efforts during World War I and II, as well as the Cold War (see Capozzola 2010; FEMA 2006; HSNPTF 2006; Oakes 1994). In fact, the USA's contemporary notion of "homeland security" is closely linked to the concept of a "civil defense," which formally emerged in the 1930s and has been a steady component of security and emergency/disaster management efforts since-although it has been re-articulated and re-purposed several times (FEMA 2006; Fosher 2009; Hay 2006; Hay and Andrejevic 2006). (And, as I have shown, the idea of situation awareness also has ties to that time period and its specific ways of thinking about security). In addition, there are also lines of continuity between the way terror-aware civilians are told to perceive of their environments and the way police officers routinely watch for signs of trouble and recognize cues of suspicion (see BJA n.d.: 20; Dunham et al. 2005; Johnson and Morgan 2013; Stroshine et al. 2008; Skolnick 2010).

Reflected in contemporary civilian terror awareness is thus a unique amalgam of different governing logics and knowledge practices. On the one hand, the injunction to "be aware and prepared" connects to different historical antecedents. On the other hand, with its emphasis on anticipation and resilience, it also establishes its 
own distinct sensory regime related to the USA's "war against terror." Perhaps the most marked difference, however, stems from the fact that terror-aware individuals are putting their "eyes and ears" at the service of the state at a time where "war" has become domesticated and de-territorialized. As noted earlier, the idea that the threat of terror is pervasive and permanent serves as the ideological legitimation for encouraging (self-)government through situational terror awareness. But where the entire domestic terrain has been re-constructed as a "battlespace" (Graham 2009), it becomes difficult "to identify both what threatens and what is threatened" (Petersen and Tjalve 2013: 7). Suddenly, all citizens are carrying within themselves the potential for "becoming-terror(ist)" (Packer 2006); all spaces frequented by people are potentially "becoming-dangerous;" and all constellations of people and things are situations on the verge of "becoming-threat." This means that while other practices of watchfulness target(ed) specific individuals or behaviors (see Reeves 2013), terror awareness necessarily targets everyone. When it comes to terror awareness, everyone is (at least theoretically, see Nguyen 2019) a potential "suspect." And as the publicly available lists of pre-incident indicators reveal, criminality is not a prerequisite. Completely innocuous behaviors suffice to establish a degree of "deviance" or "abnormality" that warrants intervention. Here, the governmental focus on situations, subjectively defined based on these indicators and an individual's "hunches," introduces an unprecedented degree of ambiguity and, hence, arbitrariness.

The extent to which governmental discourses of terror awareness are actually reshaping the perceptive practices of American citizens is difficult to assess. To date, there is no research that addresses this question specifically. A national Gallup poll conducted in December 2013 tried to assess how many Americans had heard of the government's most prominent public awareness campaign, called If You See Something, Say Something. The results were mixed. ${ }^{3}$ Despite the DHS's national roll-out of the campaign in 2011, in conjunction with the announcement of its first Strategy for Countering Violent Extremism (CVE), the authors of the poll found large differences across regions, especially between the east and west coasts of the USA. The educational background of respondents also seemed to make a difference. But this poll only examined people's awareness of the campaign, not the extent to which the campaign had actually modified their perceptive practices or increased their vigilance. Regardless of the lack of any solid data, however, from the point of view of the authorities, the governmental effort to foster "a culture of awareness and preparedness" (DHS 2018a: 16) has been a success. While pointing to cases in which a tip provided by an aware citizen has enabled law enforcement to intercept and prevent future acts of terror, both government and security officials continue to emphasize that "vigilance works" (see, for example, Difo 2010; FEMA 2012: 3; Jenkins 2017: 34-35).

At the same time, recent academic scholarship is beginning to unravel what happens to the social fabric when citizens are encouraged to view everything through a lens of (in)security and suspicion. These scholars are exploring what happens when

\footnotetext{
3 See: https://news.gallup.com/poll/166622/something-say-something-unfamiliar-americans.aspx (accessed 3 August 2019).
} 
attention becomes focused on the ever-present possibility for terror and "military sensibilities" become "the private consciousness of daily life" (Ochs 2011: 113). They are questioning what happens when sight becomes "weaponized" (Trottier 2017). And they are examining the politics of identification that accompanies discourses of vigilance and suspicion (only to find significant racial disparities in the way the accompanying practices play out, see Arfsten 2018; Breen-Smyth 2014; Mythen et al. 2009; Nguyen 2019). More research is needed in these respects for civilian terror awareness. Yet, based on what we already know, it seems well possible that the practice of terror awareness is not as neutral as it is made out to be by the authorities who are promoting it. They may be telling the public to "only report suspicious behavior and situations," and not to focus on such factors as race, ethnicity and/or religious affiliation (see DHS 2019f). But translated into concrete, instantaneous practice, this advice becomes messy. Identifying and recognizing situations of potential threat in the here and now is not as straightforward or "common sense" as the authorities would have us believe. Surely, with training, the process can become habitual, automated, and thus faster, but it cannot do away with the fact that perceptive practices are always profoundly cultural. And this makes them deeply political-even more so in cases where the perceptive field is turned into the terrain on which everyday social relations and interactions are ordered.

Acknowledgements Open access funding provided by Max Planck Society. I thank Prof. Dr. Dr. HansJoerg Albrecht and the anonymous reviewer for their constructive comments on an earlier draft of this article.

Open Access This article is distributed under the terms of the Creative Commons Attribution 4.0 International License (http://creativecommons.org/licenses/by/4.0/), which permits unrestricted use, distribution, and reproduction in any medium, provided you give appropriate credit to the original author(s) and the source, provide a link to the Creative Commons license, and indicate if changes were made.

\section{References}

Adey P (2014) Security atmospheres or the crystallization of worlds. Environ Plan D Soc Space 32:834-851

Afdile M, Jääskeläinen IP, Glerean E, Smirnov D, Alho J, Äimälä A, Sams M (2019) Contextual knowledge provided by a movie biases implicit perception of the protagonist. Soc Cognit Affect Neurosci 14(5):519-527

Alpert GP, Dunham RG, Stroshine M, Bennett K, MacDonald J (2004) Police officer's decision making and discretion: forming suspicion and making a stop. Report to The National Institute of Justice

American Civil Liberties Union (ACLU) (2009) Settlement for handcuffing and detention of UW art professor. https://www.aclu-wa.org/news/settlement-handcuffing-and-detention-uw-art-professor. Accessed 19 Aug 2019

American Public Transportation Association (APTA) (2012) Recognizing and responding to unattended packages, objects and baggage. https:/www.apta.com/wp-content/uploads/Standards_Documents/ APTA-SS-SRM-RP-007-12.pdf. Accessed 15 Sept 2019

American Public Transportation Association (APTA) (2013) Security operations for public transit. https ://www.apta.com/wp-content/uploads/Standards_Documents/APTA-SS-SIS-RP-012-13.pdf. Accessed 15 Sept 2019

Anderson B (2010) Preemption, precaution, preparedness: anticipatory action and future geographies. Prog Hum Geogr 34(6):777-798 
Anderson B, Adey P (2011) Affect and security: exercising emergency in 'UK civil contingencies'. Environ Plan D Soc Space 29(6):1092-1109

Aradau C (2010) The myth of preparedness. Radic Philos 161:2-7

Aradau C (2015) The signature of security: big data, anticipation, surveillance. Radic Philos 191:21-28

Arfsten K-S (2018) Under watchful eyes: public vigilance in the post-9/11 United States. Unpublished Dissertation. Albert-Ludwigs-Universität, Freiburg

Arizona Counter Terrorism Information Center (ACTIC) (2019) Terrorism. https://azactic.gov/content/ terrorism. Accessed 2 Aug 2019

Arizona Department of Homeland Security (AZDOHS) (2019) During an emergency-terrorism. https:// azdohs.gov/during-emergency-terrorism. Accessed 2 Sept 2019

Becker MH (2019) When extremists become violent: examining the association between social control, social learning, and engagement in violent extremism. Stud Confl Terror. https://doi. org/10.1080/1057610X.2019.1626093

Berkowitz A (2009) Response-ability: a complete guide to bystander intervention. Beck \& Co, Chicago

Berwyn Police Department (BPD) (2019) What is suspicious activity? http://www.berwynpd.com/gener al_information/what_is_suspicious_activity. Accessed 12 Aug 2019

Biesecker B (2007) No time for mourning: the rhetorical production of the melancholic citizen-subject in the war on terror. Philos Rhetor 40(1):147-168

Bissell D (2007) Animating suspension: waiting for mobilities. Mobilities 2(2):277-298

Blumer H (1962) Society as symbolic interaction. In: Rose AM (ed) Human behavior and social processes. Houghton Mifflin Co., Boston, pp 179-192

Boltanski L (2014) Mysteries and conspiracies: detective stories, spy novels and the making of modern societies. Polity Press, Cambridge

Bratich J (2002) Cultural studies, immanent war, everyday life. Cult Stud 2(1):20-23

Bratich J (2006) Public secrecy and immanent security: a strategic analysis. Cult Stud 20(4-5):493-511

Breen-Smyth M (2014) Theorizing the 'suspect community:' counterterrorism, security practices, and the public imagination. Crit Stud Terror 7(2):223-240

Brehm S, Kassin S, Fein S (2002) Social psychology. Houghton-Mifflin, Boston

Brown MJ (n.d.) The concept of 'situation' in John Dewey's logic and philosophy of science. https:// www.matthewjbrown.net/professional/papers/situation-science.pdf. Accessed 12 Aug 2019

Bureau of Justice Assistance (BJA) (n.d.) USAonWatch: the national face of neighborhood watch. Department of Justice, Washington, DC. https://www.bja.gov/publications/nsa_nw_manual.pdf. Accessed 2 Sept 2019

Capozzola C (2010) Uncle Sam wants you: World War I and the making of the modern American citizen. Oxford University Press, Oxford

Chandler D (2014) Beyond good and evil: ethics in a world of complexity. Int Polit 51(4):441-457

City of Chicago (2019) The City of Chicago and cook county remind you to report suspicious activity. https://www.chicago.gov/content/dam/city/depts/oemc/supp_info/SeeSomethingSaySomething. pdf. Accessed 10 Sept 2019

City of Henderson (2019) See something, say something, do something! https://www.cityofhenderson .com/seesaydosomething/home. Accessed 2 Oct 2019

City of Wheeling (2019) Terrorism awareness for citizens. https://www.wheelingil.gov/251/TerrorismAwareness-for-Citizens. Accessed 2 Oct 2019

Clarke RV, Newman GR (2006) Outsmarting the terrorists. Praeger Security International, Westport

Coaffee J, Fussey P (2015) Constructing resilience through security and surveillance: the politics, practices and tensions of security-driven resilience. Secur Dialogue 46(1):86-105

Colorado Office of Emergency Management (COEM) (2018) Domestic preparedness: a practical guide to help the citizens of Colorado prepare for terrorism. Colorado Department of Local Affairs, Golden. https://www.jcmh.org/RedPages/WHITE/NUMBERS/domprep.pdf. Accessed 20 Sept 2019

Connolly W (2002) Neuropolitics: thinking, culture, speed. University of Minnesota Press, Minneapolis

Cronin C (2019) The threatening rise of non-islamic terror and extremism in the west. https://www.ameri cansecurityproject.org/the-threatening-rise-of-non-islamic-terror-and-extremism-in-the-west/. Accessed 2 Oct 2019

Dallas Police Department (DPD) (2019) Recognizing suspicious activity. https://dallaspolice.net/commu nitys/rsa. Accessed 12 Aug 2019

Damasio A (1995) Descartes ‘error: emotion, reason and the human brain. Picador, London 
Derrida J (2003) Autoimmunity: real and symbolic suicides. In: Borradori G (ed) Philosophy in a time of terror: dialogues with Jürgen Habermas and Jacques Derrida. University of Chicago Press, Chicago, pp 85-136

Dewey J (1938) The theory of inquiry. https://archive.org/stream/JohnDeweyLogicTheTheoryOfInqui ry/\%5BJohn_Dewey\%5D_Logic_-_The_Theory_of_Inquiry_djvu.txt. Accessed 2 July 2019

Difo G (2010) Ordinary measures, extraordinary results: an assessment of foiled plots since 9/11. American Security Project, Washington, DC. https://www.americansecurityproject.org/wp-content/uploa ds/2010/09/Foiled-Plots.pdf. Accessed 1 June 2018

Docobo J (2005) Community policing as the primary prevention strategy for homeland security at the local law enforcement level. Homeland Secur Aff 1(1):no pagination

Dunham R, Alpert G, Stroshine M, Bennett K (2005) Transforming citizens into suspects: factors that influence the formation of police suspicion. Police Q 8(3):366-393

Endsley M (1995) Toward a theory of situation awareness in dynamic systems. Hum Factors 37(1):32-64

Federal Bureau of Investigations (FBI) (2019) Confronting the rise of domestic terrorism in the homeland. Statement by Michael C. McGarrity, Assistant Director Counterterrorism Division, before the House Homeland Security Committee, 8 May. https://www.fbi.gov/news/testimony/confrontin g-the-rise-of-domestic-terrorism-in-the-homeland. Accessed 2 Sept 2019

Federal Emergency Management Agency (FEMA) (2006) Civil defense and homeland security: a short history of national preparedness efforts. Report by the Homeland Security National Preparedness Task Force. Washington, DC. https://training.fema.gov/hiedu/docs/dhs $\% 20$ civil $\% 20$ defense-hs $\% 20$ -\%20short\%20history.pdf. Accessed 12 Aug 2019

Federal Emergency Management Agency (FEMA) (2012) Improving the public's awareness and reporting of suspicious activity. https://www.theiacp.org/sites/default/files/2018-07/SARResourceGuid e.pdf. Accessed 3 June 2019

Federal Emergency Management Agency (FEMA) (n.d.) Terrorism and WMD awareness in the workplace. Terrorism Awareness Training Course. https:/www.fema.gov/pdf/government/grant/bulle tins/info249a.pdf. Accessed 13 Aug 2019

Federal Transit Administration (FTA) (2007) The mark. https://youtu.be/uJHvrPB1ck0. Accessed 23 Aug 2019

Finney N (2008) Human terrain team handbook. Department of the Army, Human Terrain System Program, Fort Leavenworth

Flach JM (2015) Situation awareness: context matters! A commentary on endsley. J Cognit Eng Decis Mak 9(1):59-72

Floud J (1982) Dangerousness and criminal justice. Br J Criminol 22:213-228

Flynn S (2004) The neglected home front. Foreign Aff 83(5):20-33

Focuault M (2007) Security, territory, populations: lectures at the college de France 1977-1978. Transl. by G. Burchell. Palgrave, London

Fosher K (2009) Under construction: making homeland security at the local level. The University of Chicago Press, Chicago

Foucault M (1977) Discipline \& punish: the birth of the prison. Random House, New York

Fracker M (1991) Measures of situational awareness: review and future directions. Armstrong Laboratories, Wright Patterson Air Force Base, Ohio. https://apps.dtic.mil/dtic/tr/fulltext/u2/a262672.pdf. Accessed 12 Aug 2019

Franks T (2011) Statement before the subcommittee on the constitution/committee on the judiciary on H.R. 963: see something, say something act of 2011. U.S. House of Representatives, 24 June. https ://www.hsdl.org/?view\&did=705577. Accessed: 23 Apr 2019

Freilich J, Newman GR (2009) Reducing terrorism through situational crime prevention. Lynne Rienner Publishing, Boulder

Friedrichs J (1974) Situation als soziologische Erhebungseinheit. Zeitschrift für Soziologie 3(1):44-53

Giroux H (2008) The politics of emergency versus public time: terrorism and the culture of fear. Culture Machine, InterZone. https://www.culturemachine.net/index.php/cm/article/view/240/221. Accessed 2 Nov 2018

Goffman E (1964) The neglected situation. Am Anthropol 66(6):133-136

Goffman E (1971) Behavior in public spaces: notes on the social organization of gatherings. The Free Press, New York

Goffman E (1974) Frame analysis: an essay on the organization of experience. Northeastern University Press, Boston

Graham S (2009) The urban 'battlespace'. Theory Cult Soc 26(7-8):278-288 
Greenberg MA (2005) Citizens defending America: from colonial times to the age of terrorism. Pittsburgh University Press, Pittsburgh

Greene JR (2011) Community policing and terrorism: problems and prospects for local community security. In: Frost B, Greene JR, Lynch JP (eds) Criminologists on terrorism and homeland security. Cambridge University Press, New York, pp 208-244

Gugerty L (2011) Situation awareness in driving. In: Fisher DL, Rizzo M, Caird J, Lee JD (eds) Handbook for driving simulation in engineering, medicine and psychology. Chap 19. CRC Press, Baton Rouge

Harrald J, Jefferson T (2007) Shared situational awareness in emergency management: mitigation and response. In: Proceedings of the 40th Hawaii international conference on system sciences. IEEE

Hay J (2006) Designing homes to be the first line of defense: safe households, mobilization, and the new mobile privatization. Cult Stud 20(4-5):349-377

Hay J, Andrejevic M (2006) Introduction: toward an analytic of governmental experiments in these times: homeland security as the new social security. Cult Stud 20(4-5):331-348

Hilliard Police Department (HPD) (2019) What is a suspicious person? https://hilliardohio.gov/wp-conte nt/uploads/2018/07/suspicious-activity.pdf. Accessed 16 Aug 2019

Hoffman R (2015) Origins of situation awareness: cautionary tales from the history of concepts of attention. Special Issue J Cogn Eng Decis Mak 9(1):73-83

Hollywood JS, Snyder D, McKay KN, Boon JE (2004) Out of the ordinary: finding hidden threats by analyzing unusual behavior. RAND Corporation, Santa Monica

Homeland Security National Preparedness Task Force (HSNPTF) (2006) Civil defense and homeland security: a short history of national preparedness efforts. U.S. Department of Homeland Security, Washington, DC. https://training.fema.gov/hiedu/docs/dhs\%20civil\%20defense-hs\%20-\%20sho rt\%20history.pdf. Accessed 12 Aug 2019

Horgan J (2008) From profiles to pathways and roots to routes: perspectives from psychology on radicalization into terrorism. Ann Am Acad Polit Soc Sci 618(1):80-94

Hosenball M (2018) U.S. has more than 2,000 probes into potential or suspected terrorists. Reuters News Agency. https://www.reuters.com/article/us-usa-fbi-wray/us-has-more-than-2000-probes-intopotential-or-suspected-terrorists-fbi-director-idUSKCN1IH341. Accessed 23 Sept 2019

Jannat M, Hurwitz DS, Monsere C, Funk KH II (2018) The role of driver's situational awareness on right-hook bicycle-motor vehicle crashes. Saf Sci 110:92-101

Jasser Z (2011) Statement before the subcommittee on the constitution/committee on the judiciary on H.R. 963: see something, say something act of 2011. U.S. House of Representatives, 24 June. https ://www.hsdl.org/?view\&did=705577. Accessed 23 Apr 2019

Jeannot E, Kelly C, Thompson D (2003) The development of situation awareness measures in ATM systems. Technical Report. June 27. European Air Traffic Management Program

Jenkins BM (2017) The origins of America's Jihadists. RAND Corporation, Santa Monica

Jenkins BM, Liepman A, Willis HH (2014) Identifying enemies among us: evolving terrorist threats and the continuing challenges of domestic intelligence collection and information sharing. RAND Corporation, Santa Monica

Joh EE (2016) The new surveillance discretion: automated suspicion, big data, and policing. Harvard Law Policy Rev 10(1):15-42

Johnson RR, Morgan MA (2013) Suspicion formation among police officers: an international literature review. Criminal Justice Stud 26(1):99-114

Jones SG (2018) The rise of far-right extremism in the United States. Research Brief. Center for International \& Strategic Studies, Washington, DC

Juarez-Espinosa O, Gonzalez C (2004) Situation awareness of commanders: a cognitive model. https:// www.cmu.edu/dietrich/sds/ddmlab/papers/JuarezGonzalez2004.pdf. Accessed 12 Aug 2019

Kass SJ, Herschler DA, Companion MA (1990) Are they shooting at me? An approach to training situational awareness. In: Proceedings of the human factors society 34th annual meeting. IEEE, pp 1352-1356

Kaufmann M (2015) Exercising emergencies: resilience, affect and acting out security. Secur Dialogue 47(2):99-116

Knorr Cetina K (2009) The synthetic situation: interactionism for a global world. Symb Interact 32(1):61-87

LaFree G, Birkbeck C (1991) The neglected situation: a cross-national study of the situational characteristics of crime. Criminology 29:73-98 
Licata MJ (2008) Citizens terrorism awareness and survival manual. Loose Leaf Law Publications, New York

Los Angeles Police Department (LAPD) (2019a) What suspicious behaviors and activities should you report? http://www.lapdonline.org/iwatchla/content_basic_view/42535. Accessed 3 June 2019

Los Angeles Police Department (LAPD) (2019b) Communities against terrorism: potential indicators of terrorist activities related to construction sites. http://assets.lapdonline.org/assets/pdf/constructi on_sites.pdf. Accessed 11 Aug 2019

Los Angeles Police Department (LAPD) (2019c) Communities against terrorism: potential indicators of terrorist activities related to storage facilities. http://assets.lapdonline.org/assets/pdf/storage_facil ities.pdf. Accessed 11 Aug 2019

Maine Emergency Management Agency (MEMA) (2016) Homeland security-the individual's role. https://www.maine.gov/mema/homeland/homeland_citizen.shtml. Accessed 21 Sept 2018

Martin T (2018) Identifying potential terrorists: visuality, security and the channel project. Secur Dialogue 49(4):254-271

Martin WL, Murray PS, Bates PR, Lee PSY (2015) Fear-potentiated startle: a review from an aviation perspective. Int J Aviat Psychol 25(2):97-107

Maryland Department of Transportation (MDOT) (2019) If you see something, say something. http:// www.securetransit.org/prevent-terrorism. Accessed 12 Aug 2019

Massachusetts Bay Transportation Authority (MBTA) (2014) See something? Say something! https:// twitter.com/mbta/status/549663714710794240. Accessed 14 September 2019

Massumi B (2013) The remains of the day. In: Åhall L, Gregory T (eds) Emotion, politics and war. Routledge, Abingdon, pp 17-33

Massumi B (2015) Politics of affect. Polity Press, Malden

Matheus CJ, Kokar MM, Baclawski K (2003) A core ontology for situation awareness. In: Proceedings of sixth international conference on information fusion, Cairns, pp 545-552

Mayberry J (2018) Vigilance: staying guarded in a dangerous world. St. Louis Combat Institute, St. Louis

McAneny DJ (2008) NJ gets own terrorism tips hotline. South Jersey Times, 19 December. https://www. nj.com/south/2008/12/nj_gets_own_terrorism_tips_hot.html. Accessed 10 Aug 2019

McCauley C, Moskalenko S (2008) Mechanisms of political radicalization: pathways toward terrorism. Terror Polit Violence 20(3):415-433

McGovern G (2011) Situational awareness in terrorism and crime prevention. Perspect Terror 5(1):55-61

Metalis SA (1993) Assessment of pilot situational awareness: measurement via simulation. In: Proceedings of the human factors and ergonomics society, 37th annual meeting, pp 113-117

Metropolitan Police Department (MPDC) (2019) What is suspicious behavior? https://mpdc.dc.gov/ whatssuspicious. Accessed 17 Aug 2019

Moore M (2018) Wray warns current terrorism threat in US is 'everywhere'. The New York Post, 11 September. https://nypost.com/2018/09/11/wray-warns-current-terrorism-threat-in-us-is-everywhere/. Accessed 11 Aug 2019

Mythen G, Walklate S, Khan F (2009) I'm a muslim, but I am not a terrorist: victimization, risky identities and the performance of safety. Br J Criminol 49:736-754

National Center for Disaster Preparedness (NCDP) (2018) How to be ready in an age of low-tech terror: how new yorkers should equip themselves, beyond 'see something, say something'. https://ncdp. columbia.edu/ncdp-perspectives/ready-age-low-tech-terror-new-yorkers-equip-beyond-see-somet hing-say-something/. Accessed 24 July 2019

National Research Council (NRC) (1998) Modeling human and organizational behavior: application to military simulations. The National Academies Press, Washington, DC. https://www.nap.edu/ $\mathrm{read} / 6173 / \mathrm{chapter} / 9$. Accessed 12 Aug 2019

New Jersey Office of Homeland Security and Preparedness (NJOHSP) (2012) Terrorism awareness and prevention: participant guide. https://publicintelligence.net/new-jersey-office-of-homeland-secur ity-terrorism-awareness-and-prevention-participant-guide/. Accessed 17 Aug 2019

New Jersey Office of Homeland Security and Preparedness (NJOHSP) (2019) See something, say something. https://www.njhomelandsecurity.gov/njsars. Accessed 2 Oct 2019

New York State Division of Homeland Security and Emergency (NYDHSES) (2019a) If you see something, say something: mass gathering locations and nearby business establishments. http://www. dhses.ny.gov/oct/safeguardNY/documents/Mass-Gathering-Establishments.pdf. Accessed 11 Aug 2019 
New York State Division of Homeland Security and Emergency Services (NYDHSES) (2019b) If you see something, say something: safeguard new york. http://www.dhses.ny.gov/oct/safeguardNY/ documents/see-send-something.pdf. Accessed 2 Sept 2019

Nguyen N (2019) 'The eyes and ears on our frontlines:' policing without police to counter violent extremism. Surveillance \& Society 17(3-4):322-337

Nolan R, Latour E, Klafehn JL (2014) Framework for rapid situational awareness in the field. Technical Report, U.S. Army Research Institute for the Behavioral and Social Sciences, Fort Belvoir

O'Connor T (2019) Situational awareness. Lecture held at Wesleyan College, North Carolina. https:// www.ics.uci.edu/ ucrec/intranet/miscdocs/HSclassnotes/class3.html. Accessed 2 Aug 2019

O'Malley P (2010) Resilient subjects: uncertainty, warfare and liberalism. Econ Soc 39(4):488-509

Oakes G (1994) The imaginary war: civil defense and american cold war culture. Oxford University Press, Oxford

Ochs J (2011) Security \& suspicion: an ethnography of everyday life in Israel. University of Pennsylvania Press, Philadelphia

Office of the Director of National Intelligence (ODNI) (2017) First responder's toolbox. Hospitality industry: enhanced suspicious activity awareness assists in terrorism prevention. https://www. dni.gov/files/NCTC/documents/jcat/firstresponderstoolbox/First-Responders-Toolbox-Hospitalit y-Industry-Enhanced-Suspicious-Activity-Awareness-Assists-in.pdf. Accessed 12 Aug 2019

Office of the Director of National Intelligence (ODNI) (2019) Counterterrorism guide for public safety personnel. https://www.dni.gov/nctc/jcat/index.html. Accessed 20 Sept 2019

Orr J (2004) The militarization of inner space. Crit Sociol 30(2):451-481

Packer J (2006) Becoming bombs: mobilizing mobility in the war on terror. Cult Stud 20(4-5):378-399

Peck B, Gilbert S, Winer E, Ray RC (2016) HomCam: a wireless 360-degree wearable streaming camera for remote situational awareness. In: Proceedings of the human factors and ergonomics society. IEEE

Petersen KL, Tjalve VS (2013) (Neo)Republican security governance? US homeland security and the politics of 'shared responsibility'. Int Polit Sociol 7:1-18

Pinizzotto AJ, Davis EF, Miller CE III (2004) Intuitive policing: emotional/rational decision making in law enforcement. Law Enforc Bull 73(1):1-6

Prins H (1991) Dangerous people or dangerous situations: some further thought. Med Sci Law 31:25-36

Prokupecz S, Levenson E, Gingras B, Almasy S (2017) Source: ISIS note found near truck used in manhattan terror attack. CNN News, 6 November. https://edition.cnn.com/2017/10/31/us/new-yorkshots-fired/index.html. Accessed 20 Sept 2019

RAND Corporation (2005) 'Connecting the dots' in intelligence: detecting terrorist threats in the outof-the-ordinary. Research Brief. Santa Monica, CA. https://www.rand.org/pubs/research_briefs/ RB9079/index 1.html. Accessed 12 Sept 2019

Reeves J (2013) If you see something, say something: surveillance, communication, and citizenship in American life. NCP Press, Chapel Hill

Regan PM, Monahan T, Craven K (2013) Constructing the suspicious: data production, circulation, and interpretation by DHS fusion centers. Adm Soc 47(6):740-762

Rich ML (2016) Machine learning, automated suspicion algorithms, and the fourth amendment. Univ Pa Law Rev 164(4):871-930

Robertson C, Mele C, Tavernise S (2018) 11 Killed in Synagogue Massacre; suspect charged with 29 counts. The New York Times, 27 October. https://www.nytimes.com/2018/10/27/us/active-shooterpittsburgh-synagogue-shooting.html. Accessed 2 Oct 2019

Romero S, Fernandez M, Padilla M (2019) Massacre at a crowded Walmart in Texas leaves 20 dead. The New York Times, 3 August. https://www.nytimes.com/2019/08/03/us/el-paso-shooting. html?module=inline. Accessed 23 Aug 2019

Ruffini JA (2006) When terror comes to main street: a citizens' guide to terror awareness, preparedness, and prevention. Archangel Group, Denver

San Diego Police Department (SDPD) (2019) Reporting suspicious persons, activities, vehicles, etc. for terrorism prevention. https://www.sandiego.gov/police/services/prevention/community/reportingt errorism. Accessed 4 Sept 2019

Scarry E (2011) Thinking in an emergency. W.W. Norton \& Company, New York

Schmid A (2012) Terrorism prevention as situational crime prevention. The Hague: International Center for Counter-Terrorism. https://icct.nl/publication/terrorism-prevention-as-situational-crime-preve ntion/. Accessed 6 Oct 2019 
Seattle Police Department (SEAPD) (2019) Reporting suspicious behavior. https://www.seattle.gov/polic e/need-help/reporting-suspicious-behavior. Accessed 17 Aug 2019

Shapiro GL, Armstrong JH, Roberts K, Gordon J, Smith ER, Afman J, Sasser SM (2019) The Joint Counterterrorism Awareness Workshop Series (JCTAWS): integrating disciplines for enhanced capabilities during a complex coordinated attack. J Emerg Manag 17(3):210-212

Sharon Police Department (SPD) (2019) Potential indicators of terrorist activities related to the general public. https://www.townofsharon.net/sites/sharonma/files/file/file/terrormerge.pdf. Accessed 11 Aug 2019

Skolnick J (2010) A sketch of the policeman's working personality. In: Rice SK, White MD (eds) Race, ethnicity, and policing: new and essential readings. New York University Press, New York, pp $15-33$

Smith BL, Gruenewald J, Roberts P, Damphousse K (2015) The emergence of lone wolf terrorism: patterns of behavior and implications for intervention. In: Deflem M (ed) Terrorism and counterterrorism today, vol 20. Sociology of crime, law and deviance series. Emerald Publishing, Bingley, pp $89-110$

Stebbins RA (1967) A theory of the definition of the situation: theory and field research strategies. Can Rev Sociol Anthropol 4:148-164

Stewart S (2010) A primer on situational awareness. Security Weekly, 10 June. Strategic Forecasting, Inc. (StratFor), Austin. https://worldview.stratfor.com/article/primer-situational-awareness. Accessed 13 Aug 2019

Stewart S (2012) A practical guide to situational awareness. Security Weekly, 14 March. Strategic Forecasting, Inc. (StratFor), Austin. https://worldview.stratfor.com/article/practical-guide-situationa 1-awareness. Accessed 3 July 2018

Stieglitz O (2013) Die Kultur der Denunziation in den modernen USA. Campus Verlag, Frankfurt

Stroshine M, Alpert G, Dunham R (2008) The influence of 'working rules' on police suspicion and discretionary decision making. Police Q 11(3):315-337

Tau B (2019) Man arrested for allegedly plotting truck terror attack in Washington area. The Wall Street Journal, 8 April. https://www.wsj.com/articles/man-arrested-for-allegedly-plotting-truck-terro r-attack-in-washington-area-11554759345. Accessed 3 Oct 2019

Thackray R (1988) Performance recovery following startle: a laboratory approach to the study of behavioral response to sudden aircraft emergencies. Report. Civil Aeromedical Institute. Federal Aviation Administration, Oklahoma City

Thomas WI (2007) The definition of the situation. In: Manis JG, Meltzer BN (eds) Symbolic interaction: a reader in social psychology. Allyn \& Bacon, Boston, pp 331-336

Trottier D (2017) Digital vigilantism as weaponisation of visibility. Philos Technol 30:55-72

Ulicny B, Moskal J, Kokar M (2013) Situational awareness from social media. In: STIDS proceedings. https://www.researchgate.net/publication/259890373_Situational_Awareness_from_Social_Media . Accessed 23 Sept 2019

U.S. Department of Homeland Security (DHS) (2009) Remarks by secretary Napolitano at the council on foreign relations. http://www.dhs.gov/ynews/speeches/sp_1248891649195.shtml. Accessed 8 July 2015

U.S. Department of Homeland Security (DHS) (2011a) Remarks by secretary Janet Napolitano at the Clinton School of Public Service." https://www.dhs.gov/news/2011/08/22/remarks-secretary-janet -napolitano-clinton-school-public-service. Accessed 6 Oct 2019

U.S. Department of Homeland Security (DHS) (2011b) Testimony of secretary Janet Napolitano before the United States house of representatives committee on homeland security, 'understanding the homeland threat landscape - considerations for the 112th congress'. https://www.dhs.gov/ news/2011/02/09/secretary-napolitanos-testimony-understanding-homeland-threat-landscape. Accessed 3 Oct 2019

U.S. Department of Homeland Security (DHS) (2011c) Remarks by secretary Napolitano at the NYU School of Law and the Brennan Center for Justice, 'strength, security, and shared responsibility: preventing terrorist attacks a decade after 9/11'. https://www.dhs.gov/news/2011/06/07/remarkssecretary-napolitano-nyu-school-law-and-brennan-center-justice-strength. Accessed 3 Oct 2019

U.S. Department of Homeland Security (DHS) (2017) Did you know? Four ways DHS is working to prevent terrorism at home. https://www.dhs.gov/blog/2017/08/16/did-you-know-four-ways-dhs-worki ng-prevent-terrorism-home. Accessed 3 Oct 2019

U.S. Department of Homeland Security (DHS) (2018a) Soft targets and crowded places security plan overview. Washington, DC 
U.S. Department of Homeland Security (DHS) (2018b) If you see something, say something. national awareness day, September 25. https://www.dhs.gov/see-something-say-something/about-campaign/ seesay-day. Accessed 9 Oct 2018

U.S. Department of Homeland Security (DHS) (2019a) Preventing terrorism. https://www.dhs.gov/topic/ preventing-terrorism. Accessed 12 Sept 2019

U.S. Department of Homeland Security (DHS) (2019b) If you see something, say something. https:// www.dhs.gov/see-something-say-something. Accessed 12 Sept 2019

U.S. Department of Homeland Security (DHS) (2019c) Nationwide SAR initiative (NSI). https://www. dhs.gov/nsi. Accessed 2 Sept 2019

U.S. Department of Homeland Security (DHS) (2019d) Protect your everyday. recognize the signs of terrorism-related suspicious activity. https://www.dhs.gov/see-something-say-something/campa ign-materials/indicators-infographic. Accessed 11 Sept 2019

U.S. Department of Homeland Security (DHS) (2019e) Protect your everyday public service announcement. https://www.dhs.gov/see-something-say-something/campaign-materials/protect-your-every -day-psa. Accessed 11 Sept 2019

U.S. Department of Homeland Security (DHS) (2019f). What is suspicious activity? https://www.dhs. gov/see-something-say-something/what-suspicious-activity. Accessed 2 Oct 2019

U.S. Department of Homeland Security (DHS) (n.d.) National terrorism advisory system (NTAS). https:// www.dhs.gov/national-terrorism-advisory-system. Accessed 2 Sept 2019

U.S. Department of Justice (DOJ) (2018a) Pennsylvania man charged with federal hate crimes for tree of life synagogue shooting. https://www.justice.gov/opa/pr/pennsylvania-man-charged-federalhate-crimes-tree-life-synagogue-shooting. Accessed 12 Sept 2019

U.S. Department of Justice (DOJ) (2018b) Cesar altieri sayoc charged in 30-count indictment with mailing improvised explosive devices in connection with domestic terrorist attack. https://www. justice.gov/opa/pr/cesar-altieri-sayoc-charged-30-count-indictment-mailing-improvised-explo sive-devices. Accessed 12 Sept 2019

U.S. Transportation Security Administration (TSA) (2014) If you see something, say something. https ://www.tsa.gov/news/top-stories/2015/12/14/if-you-see-something-say-somethingTM. Accessed 12 Aug 2019

U.S. White House (WH) (2007) National strategy for homeland security. https://www.dhs.gov/xlibr ary/assets/nat_strat_homelandsecurity_2007.pdf. Accessed 12 Oct 2018

U.S. White House (WH) (2018) National strategy for counterterrorism of the United States of America. https://www.whitehouse.gov/wp-content/uploads/2018/10/NSCT.pdf. Accessed 12 Aug 2019

Verma S, Vieweg S, Corvey WJ, Palen L, Martin JH, Palmer M, Schram A, Anderson KM (2011) Natural language processing to the rescue? Extracting 'situational awareness' tweets during mass emergency. In: Proceedings of the fifth international AAAI conference on weblogs and social media, July 17-21, Barcelona

Vidulich M, Dominguez C, Vogel E, McMillan G (1994) Situation awareness: papers and annotated bibliography. The Air Force Institute of Technology, Dayton

Vieweg S (2012) Situational awareness in mass emergency: a behavioral and linguistic analysis of microblogged communications. PhD Thesis. University of Colorado at Boulder. https://works .bepress.com/vieweg/15/. Accessed 2 June 2018

Vieweg S, Hughes AL, Starbird K, Palen L (2010) Microblogging during two natural hazards events: what twitter may contribute to situational awareness. In: CHI (ACM conference on human factors in computing systems), April 10-15, Atlanta

Walters W (2016) Live governance, borders, and the time-space of the situation: EUROSUR and the genealogy of bordering in Europe. Comp Eur Polit 15(5):794-817

Warr M (1990) Dangerous situations: social context and fear of victimization. Soc Forces 68(3):891-907

Wasserman R (2010) Guidance for building communities of trust. Report. Washington, DC: U.S. Department of Justice, Office of Community-Oriented Policing Services

Western Community Policing Institute (WCPI) (2009) Creating vigilant, prepared, resilient communities for homeland security: training support package. Western Oregon University, Monmouth. http://www.wou.edu/ koboldm/CVPR/Final\%20IG\%20PG/Instructor\%20Guide\%20version\%20 Final\%20031010.pdf. Accessed 2 Oct 2019

Wickens CD (2015) Situation awareness: its applications value and its fuzzy dichotomies. J Cogn Eng Decis Mak 9(1):90-94 
Zigon J (2015) What is a situation? An assemblic ethnography of the drug war. Cult Anthropol 30(3):501-524

Publisher's Note Springer Nature remains neutral with regard to jurisdictional claims in published maps and institutional affiliations. 